Qh. 1828

\title{
MASIE
}

UCRL-52351

\section{AN AUTOMATED SAMPLE-PROCESSING AND TITRATION SYSTEM FOR DETERMINING URANIUM IN NUCLEAR MATERIALS}

J. E. Harrar, H. G. Boyle, J. D. Bresheara, C. L. Pomernack1,

H, R. Brand, A. M. Kray, R. J. Sherry, and J. A. Pastrone

November 15,1977

Prepared for U.S. Energy Research \& Development

Administration under contract No. W-7405-Eng-48

$\theta$
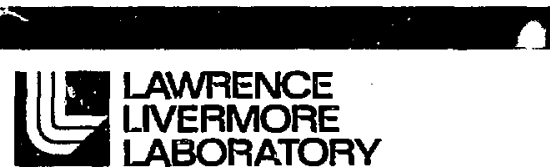

IAWRENCE

LIVERMORE LABORATORY

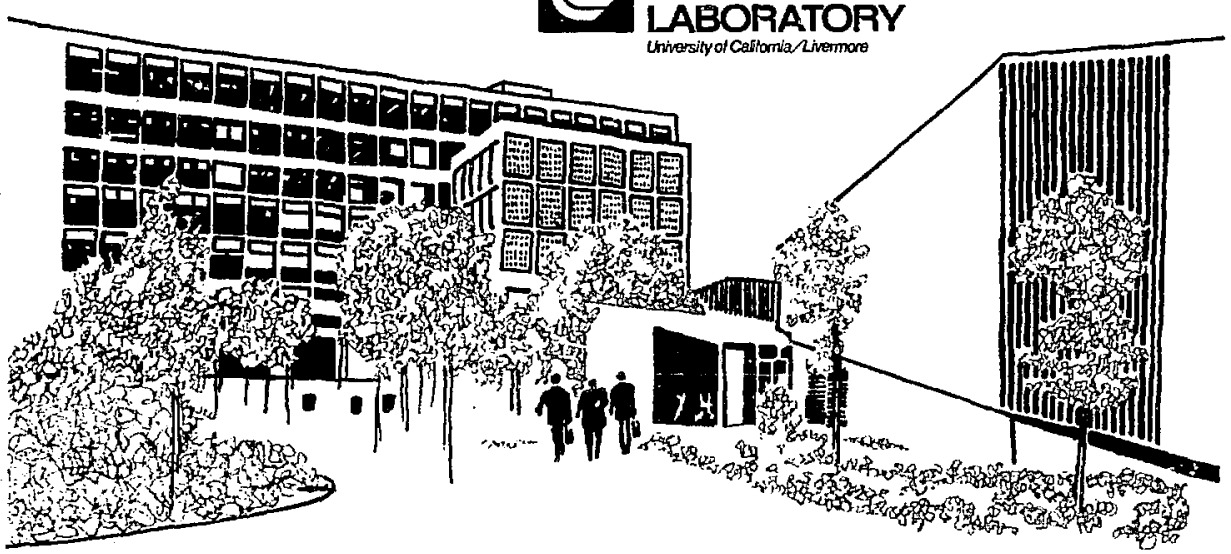

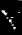




\section{NOTICE}

"This report wes prepered as en account of work iponsored by the United States Government. Neither the Unifed Statea nor the United States Department of Enetgy, not nny of their em. playees, nor any of thelr contractors, subcontructors, or their employses, mokes eny wertenty, express or inplied, or esyumes eny legal liablity or responslbillty for the accuracy, complotones or usefulnes of any informutlon, epparitus, product of process disclosed, or represents that its usewould not infringe privately-owned rights."

\section{NOTICE}

Reference to a company of product name does not imply approval or tecommendation of the product by the University of Californda or the U.S. Department of Energy to the exclusion of others that may be suitable.

Printed in the United States of America Avalable from

National Technical Information Service

U.S. Department of Commerce

528.5 Port Royal Road

Springfield, VA 22!61

Price: Printed Copy S : Microfiche $\$ 3.00$

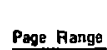

$00 \mathrm{j}-025$

026-050

051-075

$076-100$

$101-125$

$126-150$

$15 !-175$

$176-200$

201-225

$226-250$

$251-275$

276-300

$301-325$
Domestic

$$
\text { Price }
$$

54.00

4.50

5.25

6.00

6.50

7.25

8.00

9.00

9.25

9.50

10.75

11.00

11.75

Add 32.50 tor each additicnal 100 nave inctament from 601 pages up. 


\section{㢟 \\ LAWRENCE LIVERMORE LABORATOFY \\ Lhiversity of Caltomia / Livermare, Calionia/94550}

UCRL-5235I

\section{AN AUTOMATED SAMPLE-PROCESSING AND TITRATION SYSTEM FOR DETERMINING URANIUM IN NUCLEAR MATERIALS}

J. E. Harrar, W. G. Boyle, J. D. Breshears, C. L. Pomernack1, H. R. Brand, A. M. Kray, R. J. Sherry, and J. A. Pastrone

MS. date: November 15, 1977

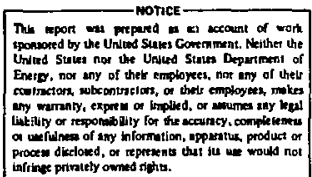




\section{CONTENTS}

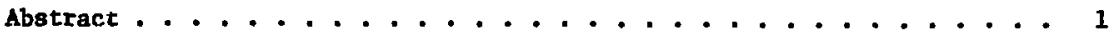

Introduction ........................ 1

System operation . . . . . . . . . . . . . . . . . 6

Welghing and Storage of Welght Data ............ 6

Loading of Sample Changer ................. 8

Analys1s and Data Readout ................ 8

Description of Electronic Hardware . . . . . . . . . . . . 10

Computer System . . . . . . . . . . . . . . . . 10

Control Panel and Fault-Monftoring Chassis . . . . . . . . 12

Electronic Balance . . . . . . . . . . . . . 12

Sample Changer .................... 12

Sample Identification System ............... 14

Programmable Constant-Current Source ............. 14

Electrode Potential Measurement Interface . . . . . . . . 14

Valve Driver Chassis ................. 16

Gas, Water, Reagent, and Waste Distribution Systems . . . . . . . 16

Reagent Delivery System ................ 16

Reagent Containment System ............... 20

Water Regulation System ..................20 20

Waste Distribution System . . . . . . . . . . . . 22

Gas Valve Chassis................... 22

Titration Cell Assembly . . . . . . . . . . . . . . . 24

Software Vescription ..................... 27

Sequence of Operations for Automated Analysis ........... 29

Between-Sample Perlod . . . . . . . . . . . . . . 29

Pretitration ................... 29

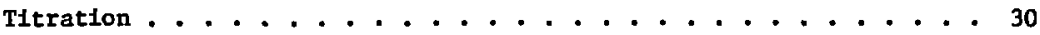

Post-Titration .................. 32

Calculation and Readout ................ 32

Return to Between-Sample Perlod .............. 33

Fault-Monttoring System .................. 33

Preliminary Studies of System Performance . . . . . . . . . 36

Solution Delivery System ................. 36

Reagent Solution Purfty ................ 37

Titration Technique .................. 37 
Comparison of the Two End-Point Calculation Techniques . . . . . . . 40 Accuracy of the Constant-Current Source. . . . . . . . . . . . . 40 Evaluation by the New Brunswlk Laboratory. . . . . . . . . . . . . . . . . 41 System Rellability . . . . . . . . . . . . . . . . . . . . . . 42 Gas, Water, Reagent, and Waste Distribution Systems . . . . . . . . . 42 Electronic Systems . . . . . . . . . . . . . . . . . . . 42 Acknowledgments . . . . . . . . . . . . . . . . . . . . . . . . 44 References. . . . . . . . . . . . . . . . . . . . . . . 45 


\section{AN AUTOMATED SAMPLE-PROCESSING AND TITRATION SYSTEM FOR DETERMINING URANIUM IN NUCLEAR MATERIALS}

\section{ABSTRACT}

The system is designed for accurate, precise, and selective determination of from 10 to $180 \mathrm{mg}$ of uranium in 2 to $12 \mathrm{~cm}^{3}$ of solution. Samples, standards, and their solutions are handled on a welght basis. These weights, together with their appropriate 1dentification numbers, are stored in computer memory and are used automatically in the assay calculations after each titration. The measurement technique (controlledcurrent coulometry) is based on the Davies-Gray and New Brunswick Laboratory method, in which U(VI) is reduced to $U(I V)$ in strong $\mathrm{H}_{3} \mathrm{PO}_{4}$, followed by titration of the U(IV) with electrogenerated $V(V)$. Solution pretreatment and titration are automatic. The analyzer is able to process 44 samples per loading of the sample cinanger, at a rate of 4 to 9 samples per hour. The system Includes a comprehensive faultmonitoring system that detects analytical errors, guards against abnormal conditions which might cause errors, and prevents unsafe operation. In this report, we present a detalled description of the system, Information on the reliability of the component subsystems, and a summary of 1ts evaluation by the New Brunswick Laboratory.

\section{INTRODUCTION}

Among the numerous methods proposed for the accurate assay of uranium in nuclear materials, the titrimetric method of Davies and Gray ${ }^{1}$ as modifled by workers at the New Brurswick Laboratory (NBL) ${ }^{2}$ has emerged as the most selective and hence the most versatile technique. This method has been thoroughly characterized at aBL and elsewhere, and has been found to be especially applicable to uranyl nitrate solutions; samples such as aluminum-, stainless-steel-, and Zircaloy-clad fuels; and samples containing niobium, hydroflunric acid, and nitric acid. The original Davies-Gray method involves the reduction of $\mathrm{J}(\mathrm{VI})$ to $\mathrm{UI}$ (IV) by $\mathrm{Fe}$ (II) in strong $\mathrm{H}_{3} \mathrm{PO}_{4}$, oxidation of the excess $\mathrm{Fe}$ (II) with uNO $_{3}$ in the presence of Mo(VI) catalyst and sulfamic acld, dilution 
of the solution, and then titration of the U(IV) with $\mathrm{K}_{2} \mathrm{Cr}_{2} \mathrm{O}_{7}$ th a visual end point. The methold was improved at NBL by the addition of $V(I V)$ to the solution to acedlerate the attainment of equilibrium, thus enabling potentiometric end-polint detection. The basic method liso has been adapted by Goldbeck and herner ${ }^{3}$ of NBL to a coulometric titration, in which the $v(V)$ titrant is electrogeneratad at constant current py the oxidation of $V(I V)$. This procedure, compared to the volumetric one offers several advantages. It does not require a titrant solution, there is greater precision and lower systematic error in the measure went of the titrant quantity, it is easier to adapt to changing quantities of uranium titrated, and it is ameinable to automation.

Because of the large number of assay samples processed by many nuclear laboratorfes, there has byen a continuing need for the automatjon of a general-purpose procedure like that based on the Davies-Gray-NBL method. Other benefits such as more timely analyses, freedom from operator bias, reduced clerical time and errors, Increased preciston, and reduced operator Intervent:on when processing radioactive samples also could tye realized with automation. Howerer, to achieve the maximum benefits of automation, all operations performed on the samples, not fust the titration Itself, should be automated. Four basic steps are involved in the complete analysis: sample dissolution, sample solution preparation, titration, and calculation and presentation of the results. All of the work done to date has been directed toward mechanizing the last three steps.

Progrese in the automation of the Davies-Gray-NBL method thus far has included adapting the volumetrfi, potentiometric titration to a Fisher Scientific Company Titralyzer, ${ }^{2}$ Radiometer Company titration equipment, ${ }^{4}$ and a Brinkmann-Metrohm titrator with programable calculator control. 5 The coulometric titration also has been carried out with the F1sher Titralyzer. ${ }^{6,7}$ Recently, workers at the Reactox Centrum Nederland ${ }^{8}$ and the Hanford Englneer Ing Development Laboratories ${ }^{9}$ have succeeded In scaling down the volumetric titration and have designed the procedure for semiautomatic operation. The LlL titration system described here 1s based on the fullscale coulometric titration. ${ }^{3}$ (When our system first was designed, we did not know if the procedure could be scaled down without an intolerable loss of accuracy and precision.)

Because of the instability of the $U(I V)$, sample solutions must be handled individually, starting with the pretitration solution prepration, 
and titrated immediately. Thus, the solution preparation and titration steps should be combined in the automated system. The solution handling presents some particularly difficult problems for automation. The large volumes of reagent solutions used ( 5 to $160 \mathrm{~cm}^{3}$ ), their extremely corrosive nature (e.g., $8 \underline{\mathrm{MNO}}_{3}$ and $13 \mathrm{M} \mathrm{H}_{3} \mathrm{PO}_{4}$ ), and the total volume of the titration solution (about 250 $\mathrm{cm}^{3}$ ) precludes the use of commercially available solution dispensers and discrete-sample analyzers. 10,11 In previous work, ${ }^{2,4-9}$ the addition of the reagent solutions before the titration and the post-titration rinsing have been accomplished with systems of valves, gravity-feed reservolrs, and pumps.

The design of the automated analysis system described here extends and departs from previous systems in several respects. Flgure 1 is a photograph of the overall system and a simplified block diagram is given in Fig. 2. The system, complete with an automatic wet-cheilical analyzer,

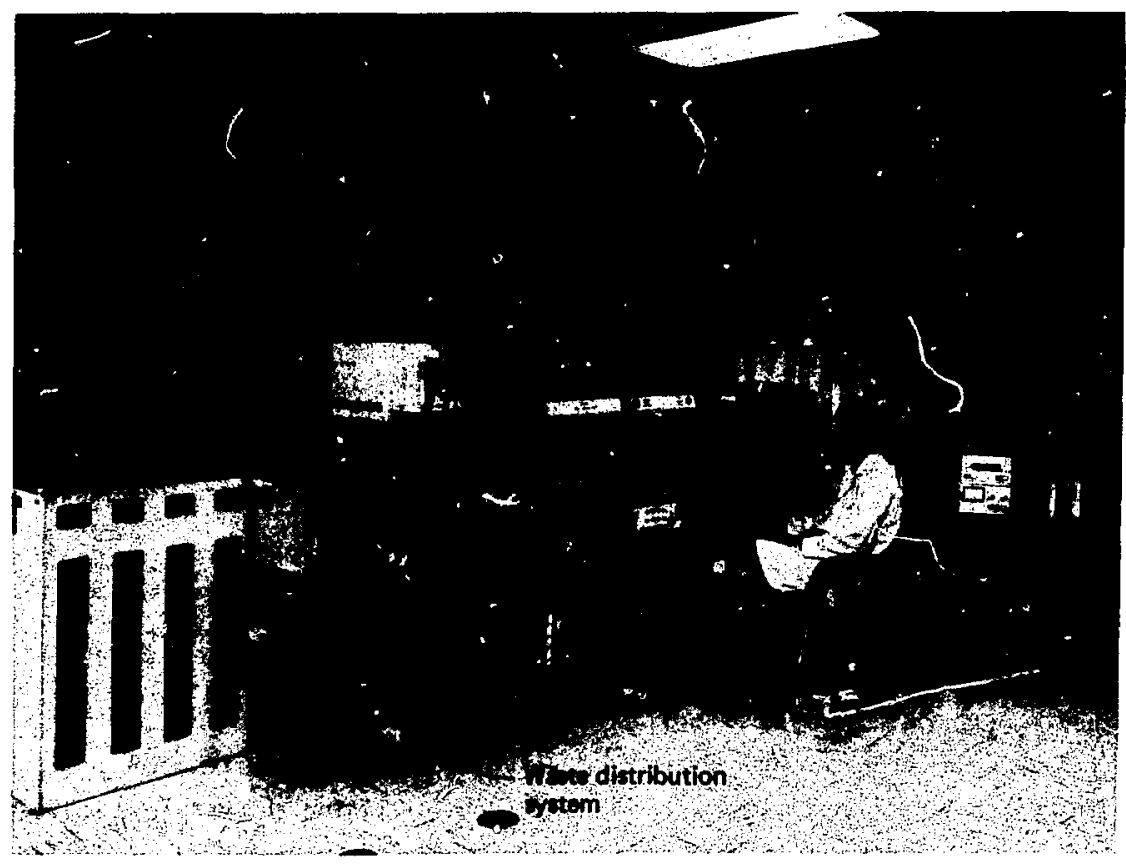

Fig. 1. LLL automated titration system for uranium. 


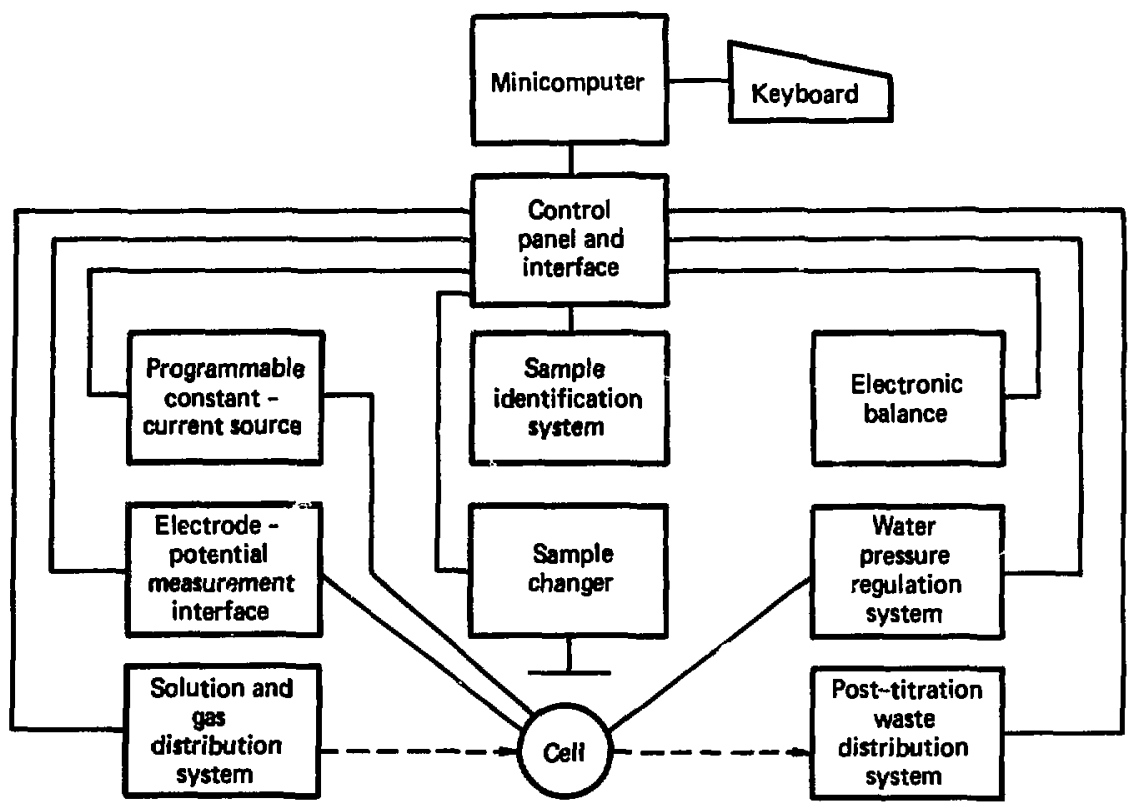

Fig. 2. Diagram of the automated titration system for uranium.

is able to handle all of the datagenerating operations associated with the assay of solid or liquid samples containing uranium. Determination of uranium is accomplished by controlled-current coulometry with potentiometric end-point detection.

Figure 3 outlines the basic procedure for the assay of urantum materlals by the Davies-Gray-NBL method. First, a subsample of solid materfal is welghed and then dissolved In all appropriate solvent (e.g., nitric acid). To reduce the systematic errors of the analysis, a weighed allquot is taken of the subsample solution. This aliquot usuall $\ddot{z}$ is evaporated with sulfuric acid to remove interferences. In the automated system, the weight information is stored semiautomatically via an electronic balance or is entered at a keyboard. After the evaporation step, all succeedin's operations are accomplished without operator attention.

The two principal operations welghing the solfd and solution samfiles and titrating the uranium in solution - have been Integrated so that previously entered weight information, 


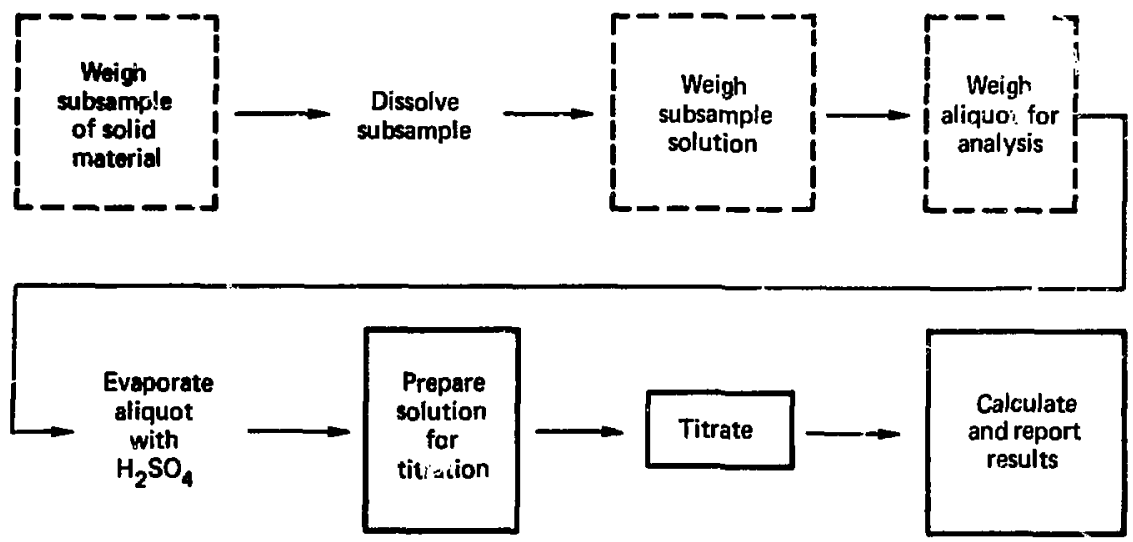

F1g. 3. Basic steps of the automated uranium assay procedure (solid and dashed boxes denote automatic and semiautomatic oporations, respectively).

with appropriate 1dentification numbers, can be extracted from a com, uter memory file and used with the titration results to automatically calculate the quantity and weight concentrations of urantum in the analyzed samples.

A commercially avallable sample changer with a capacity of forty-four 300-ml beakers is used, together with an optical-reader electronic subsystem that reads coded labels denoting the positions of the beakers in the sample changer.

The apparatus for delivering the pretitration reagent solutions and discarding the waste solution uses pressurized solution containers and an appropriate valving arrangement, rather than a pump system. (Somewhat similar approa thes to solution dispensing have been used recently in liquid chromatography ${ }^{12}$ and for titrant solution delivery. ${ }^{13}$ ) Titrations are performed by controlledcurrent coulometry using a spectally designed electrolysis cell as well as electronic modules for programming the current and for measuring the electrode potentials. 14

Another essential feature of the uranium titration system is an extensive fault-condition monitoring subsystem that guards against unsafe operating conditions and abnormal conditions that might cause incorrect analytical results. This faultmonitoring network includes sensors for solution spills or leaks, solution flows, gas and water pressures, and power outages. In addition, sof tware is provided for detecting abnormal characteristics in the titration 
itself and for determining whether the anslyses of standard solutions are within quality-control Iimfta. if any of the fault conditions should occur, the system is programmed to give an alarm and indicate and record the fault. The system then shuts down, goes on hold, or carries out certain preprogrammed actions, depending on the nature of the fault condition and the status of the system when the fault occurred. In addition, this fault-condition subsystem automatically monitors many parameters more carefully than could be done manually, thus significantly increasing the credibility of the analytical results and minimizing the probability of incorrectly processing large numbers of samples.

\section{SYSTEM OPERATION}

There are three basic steps in the overall operation of the uranium titration system: weighing the sample, loading the sample changer, and the actual analysis.

\section{WEIGHING AND STORAGE OF WEIGHT DATA}

First, a series of weights, from which the weight concentration of uranium will be calculated, are entered Into the computer memory file along with appropriate identification (ID) numbers. For unknown samples, three weights are entered: the subsample weight (the portion of the solid sample to be analyzed), the subsample solution weight (the solution resulting from the dissolution of the subsample), and the subsample solution allquot weight (the allquot of the subsample solution to be titrated). The operations and the iD number coding are illustrated in Fig. 4.

For known standard solutions, the weight of the allquot of standard solution and the concentration of the standard solution are entered; the computer calculates only the quantity of uranium in the standard aliquot and stores this value with the ID number for later use. The ID numbers for standards consist of one letter followed by 4 digits, e.g., A1234.

A sample omputer printout 111ustrating the eir.y of data for a sample and for a standard is shown in Fig. 5. In this dialogue, the operator can type in a numerical value of the weight or cause an automatic entry of the weight from the electronic balance by typing a carrlage return. The three weights for a sample usually are not all 


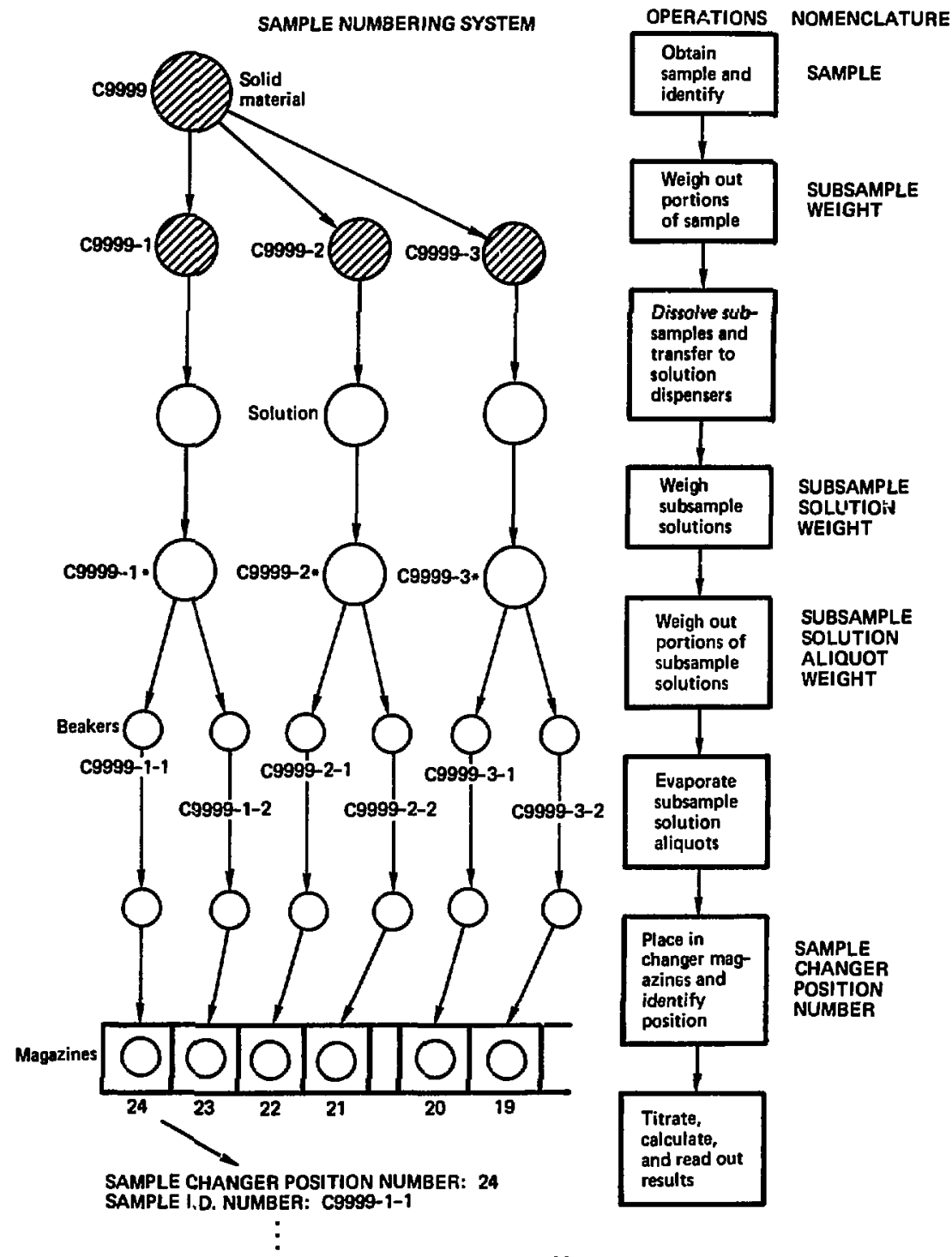

MG. NORMAL URANIUM IN SAMPLE ALIQUOT: 80.432

Fig. 4. Processing scheme for solid samples. 
DATE EHTERED: $04-01-76$

J. D. NUMBER: E2949-1-2

SUBSAMPLE HT. , BM. : 006. 32521

SUBSAHPLE SOL. HT. GM. : 025. 21800

SUBSAMPLE SOL. RL10UDT UT., GH. :010. 28540

DATE ENTERED: 04-01-76

1. D. NUMEER : $A 0910$

STD. ALIQUOT HT. GM. :009. 43420

5TD. CONC., NG. URANIUM/OM. SOLH. : 10.952

STD. QUAHTITY OF URRHIUM, MG. : 103.32300

FIg. 5. Entry of welght data for a sample and a standard.

entered at the same session because of intervening chemical pretreatments. In this case, each time a new weight Is to be entered, the previously entered weights are automatically recalled and printed by the program, In response to the operator's typing of the appropriate ID number. W1th the automatic tare feature of the electrontc balance, entry of a sertes of atandard solution welghts and aliquots of subsample solutions is very rapid.

\section{LOADING OF SAMPLE CHANGER}

After a group of samples and standards have been welghed and prepared for titration, the beakers are placed in the sample-changer magazines. The operator, interacting with the computer, then enters the required data into the computer mewory files: namely, the ID number of each subsample solution allquot or etandard quantity of uranium and the numbers of the asgazine positions in which he has placed beakers. The input format for this step is illustrated In Fig. 6. In this dialogue, the computer requests the data Indicated for each beaker. (The current month, day, and year are entered only once.) Later, when the sample changer operstes during the analytical cycle, the sample identification subgystem Identifies each beaker by position number as its solution is analyzed. After the titration is complete and the quantity of urantun calculated, the computer assoclates the uranium quantity via the position number to the previously eltered ID number and weight information.

ANALYSIS AND DATA READOUT

After loading the sample changer and indexing the position numbers to the ID numbers, the hardware and software systems are ready for the titraton step. At the Inttial startup, there is another computer-operator exchange, during which the operator

$$
\begin{aligned}
& \text { DATE: 04-01-76 } \\
& \text { SAHPLE POS. NUHBER : } 21 \\
& \text { I. D. NUMBER : ROQ11 } \\
& \text { DATE : 04--91-76 } \\
& \text { SAHPLE POS. NUMBER::22 } \\
& \text { I. D. NUMBER : E2849-1-1 } \\
& \text { DATE : } 94-01-76 \\
& \text { SRMPLE POS. NUMBER : : } 23 \\
& \text { I. D. MUHBER: E2849-1-2 }
\end{aligned}
$$

Fig. 6. Entry of sample-changer position numbers and ID numbers for a standard and two samples. 
specifies certain parameters that govern the titration and data gathering. Figure 7 1llustrates the operations that are required to inftiate and execute the analytical cycle. (The rectangular blocks represent discrete operation status perlods that provide the framework for the normal-operating and faultmonitoring software.) After each beaker is processed, the result of the analysis is printed out with the previously entered weight data as well as with information on titration characterlstics that may be useful for diagnostic purposes (see Figs, 8 and 9) "For the standard solution (Fig, 9), an error is calculated and this value is compared with a previously set control tolerance. A system halt ia initiated if the error is too large. With the positive sample identification features of this system, samples and standards can be loaded and procesged in any proportion and In any order.

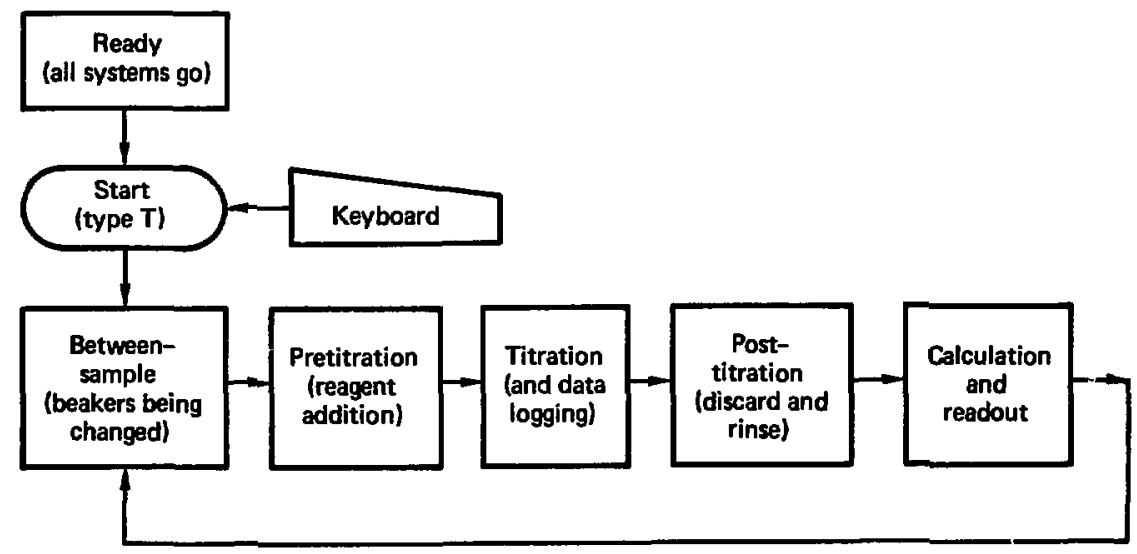

Fig. 7. Sequence of operations in the analytical procedure. 


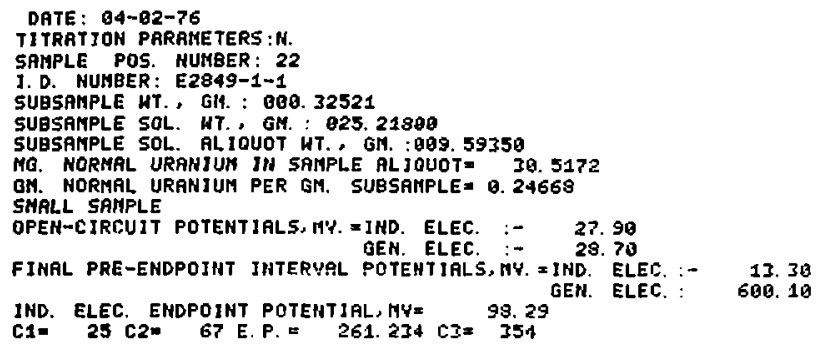

F18. 8. Data readout for the analysis of a sample.

DATE: 03-31-76

TITRATION PARAMETERS : $N$.

SAMPLE POS. NUMBER: 27

1. D. MUHBER: AOQBS

STO. RUAHTITY OF URANIUM, MG. : 085. 98192

MO. IORHPL USANIUA IN STO. ALIQUOT, MO.

ERROR: 0. 011\%

OPEN-CIRCUIT POTENTIRLS, MY. =IMD. ELEC. :- 46. 28

GEN. ELF.C. :- 47. 30

Final PRE-ENDPotnt Interyal POTENTIALS, MY, =1ND. ELEC. :- 20.50

IND. ELEC. ENDPOIHT POTENTIAL, MY= 169.34

C1. 6 C2: 11$]$ E.P. $=364896 \mathrm{c} 3 \mathrm{~J} 45$

F1g. 9. Data readout for the analysis of a standard.

\section{DESCRIPTION OF ELECTRONIC HARDWARE}

A detailed block diagram of the uranium titration system, showing the various electronic and electromechanical modules and their functional relationships, is given in Fig. 10.

\section{CONPUTER SYSTEM}

The supervisory computer system Includes a Digltal Equipment Corporation model PDP-8/e mint-computer with $24 \mathrm{~K}$ of core memory, a mode1 LA-30 Decwriter keyboard, a fast paper-tape reader and punch, a DKB-EP programmable real-time clock, an MI8-EP bootstrap leader, a KP8-E power-fall detector, and the assoctated interfaces (see Fig. 1). The accuracy of the programmable clock is critical to the analysis. The clock frequency Is specified to be $10 \mathrm{MHz}( \pm 0.01 \%)$ over the 0 to $55^{\circ} \mathrm{C}, 10$ to $90 \%$ relative humldity operating range of the computer and was verifled at $25^{\circ} \mathrm{C}$ by measurement with an electronic counter. 


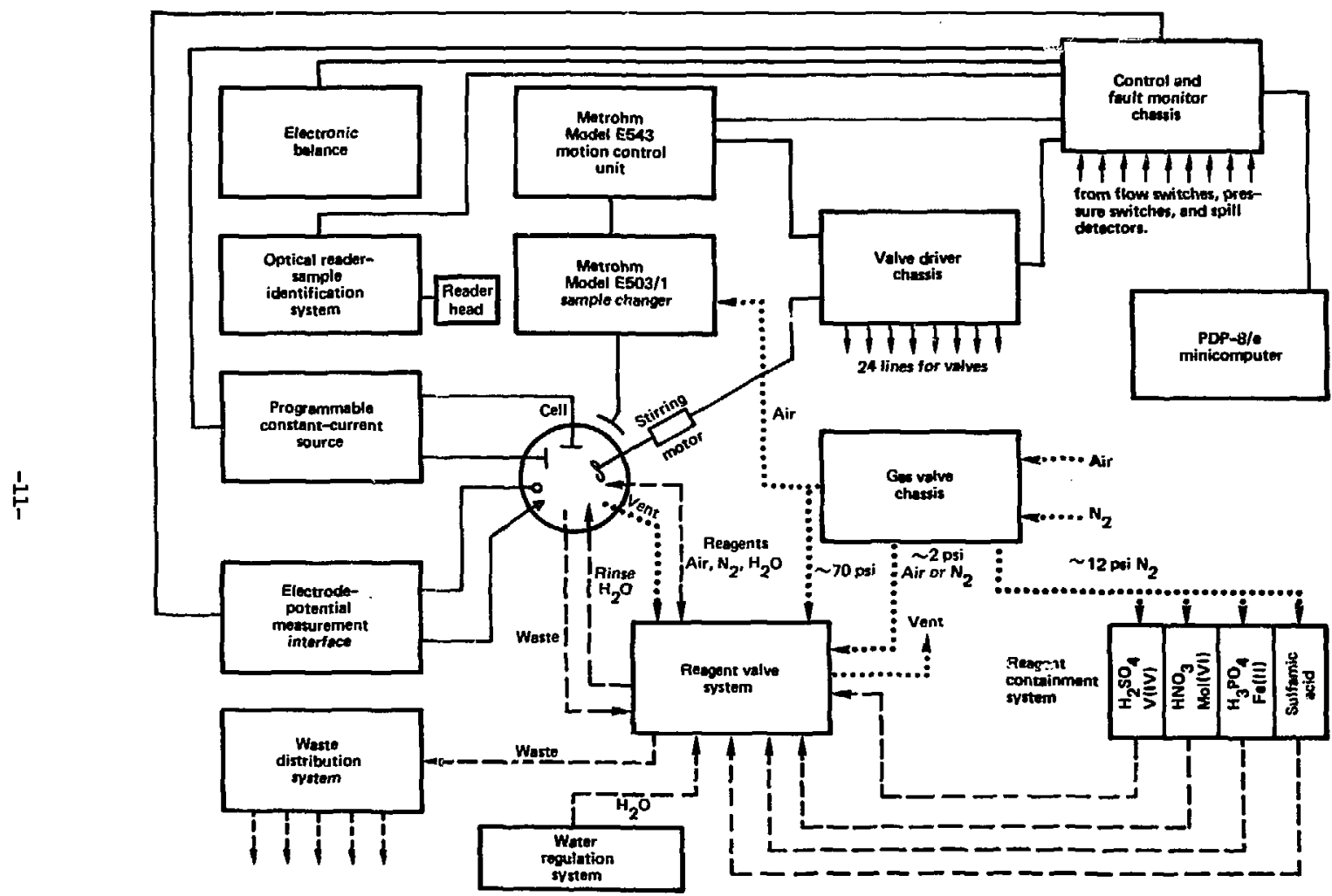

Fig. 10. Diagram of the automatic uranium titration systeni. 
CONTROL PANEL AND FAULT-MONITORING CHASSIS

This unit (see Figs. 11 and 12) incorporates most of the digital logic and interfacing that link the computer with the rest of the system. Signals from the various hardware fault-monttoring sensors arrive at this chassis. On the control panel, a graphic diagram of the solution, Bas, water, and waste flow system is provided, together with switches that allow operator mantpulation of the system valves to manual1y conduct some of the system functions. The array of lamps indicates valve status, flutd flow, operation status of the

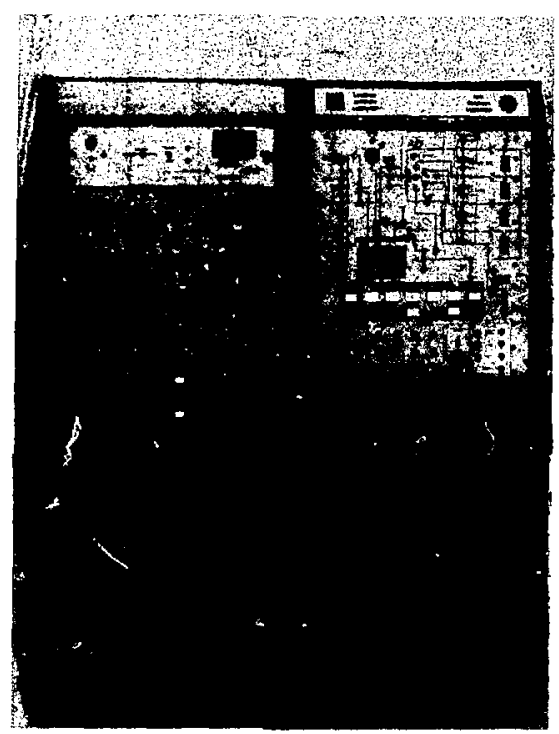

F1g. 11. System control console. system, and system faults as they occur.

\section{ELECTRONIC BALANCE}

The electronic balance (3i. Fig, 1) is a Mettler Instrumfat Corporation mode1 HE10/BE10 balanc $;$ 'control unit, with a BA28 digital display module. BInary-coded dectmal (BCD) signals are taken from the BA28 module to the control panel interfice where the weight information is logged in. The balance has a maximum capacity of $160 \mathrm{~g}$, a readibility of $0.1 \mathrm{mg}$, and an automatic tare feature that enables zeroing of the readout over the entire weight range.

\section{SAMPLE CHANGER}

The samples to be titrated are acid solutions of uranium in volumes up to about $12 \mathrm{~cm}^{3}$, contained in special, 11pless beakers. The beakers are queued for titration on a Metrohm Ltd, model E503/1 pneumatic sample changer $^{15}$ (see Fig. 1). The sample changer is under the direct control of a mode1 E543 sample-changer control unit, which in turn is controlled by the computer. The beakers are transported on the sample changer in fourplace plastic magazines (FIg. 13); there is space for 11 magazines in one loading of the sample changer. The regular titration station and all accessortes were removed from the model E503/1 sample changer, leaving 

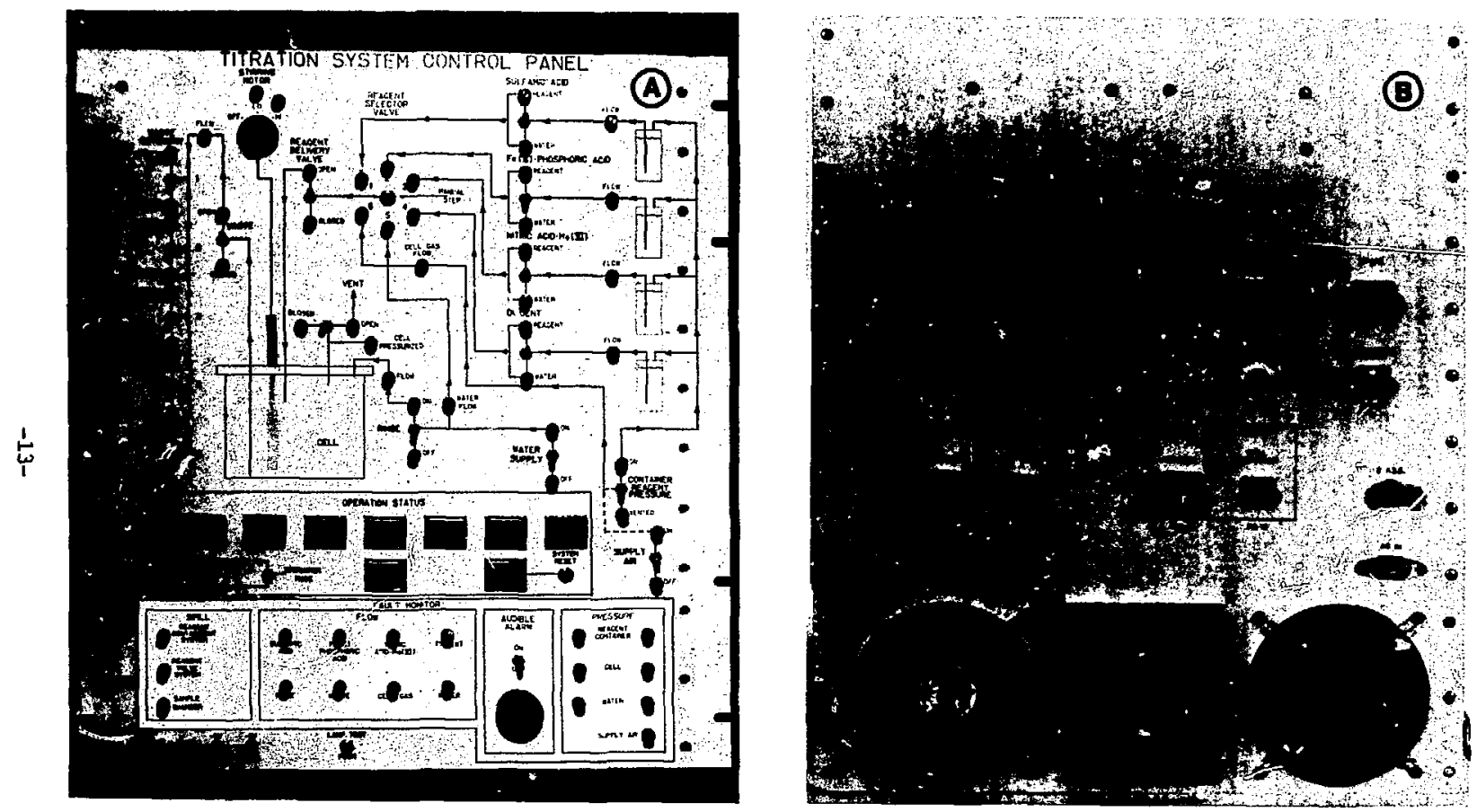

Fig. 12. Control panel and fault monitor chassis, front (a) and rear (b). 
only the four support rods. A new titration station and the reagent valve system were attached to these rods.

\section{SAMPLE IDENTIFICATION STSTEM}

The sample identification subsystem consists of three modules manufactured by the Mettler Instrument Corporation: a model CT21I optical code reader (Fig. 13), a model CT21 code reader control, and a model CT16 numerical deplay. Blnary-coded decimal signals from the numerical display unt are taken to the control panel interface. Reflectlve, adheolve-backed, coded labels are affixed to the positions on the sample changer magazines. As the aample magazine 18 moved past the titration station, bringing a new sample into position, the optical reader (mounted at the titration station) deciphers the label. The

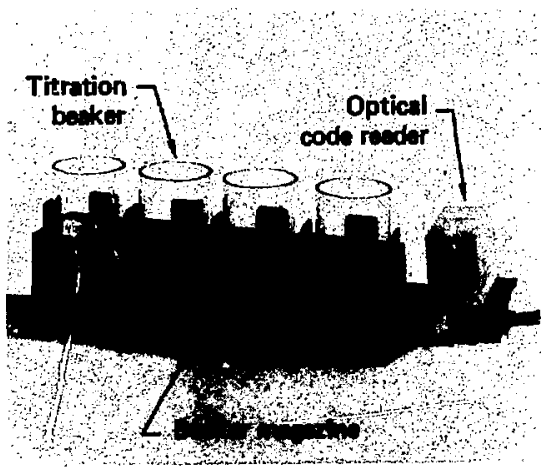

FIg. 13. Beakers in magazine with optical code reader. number corresponding to the position of the beaker in the magazine is transmitted to the computer. These position numbers have been previously linked by the operator to the particular sample ID number. Elght-digit number $a$ can be accommodated by the reader system; presently however, only two-digit numbers (I through 99) are used.

PROGRAMMABLE CONSTANT-CURRENT SOURCE

This module is described more completely In Ref, 14 and is 11lustrated in Fig. 14, It permits digital control of direct current to $500 \mathrm{~mA}$ with a resolution of approximately $30 \mu \mathrm{A}$ and a compllance voltage of more than $45 \mathrm{~V}$. In addition, all Instrument functions can be controlled manually with the front panel switches. A built-in digital panel meter enables the system to measure, visually Indicate, and transmit (as BCD $s 1 g-$ nals) elther the delivered constant current (as the voltage drop across a built-1n prectsion resistor) or the total output voltage of the source. Switching between these two measurements can be controlled externally. The long-term stability of the instrument calibration is $0.03 \%$ per year. ${ }^{14}$

ELECTRODE POTENTIAL MEASUREMENT INTERFACE

This untt (also described more fully in Ref. 14) provides a means 

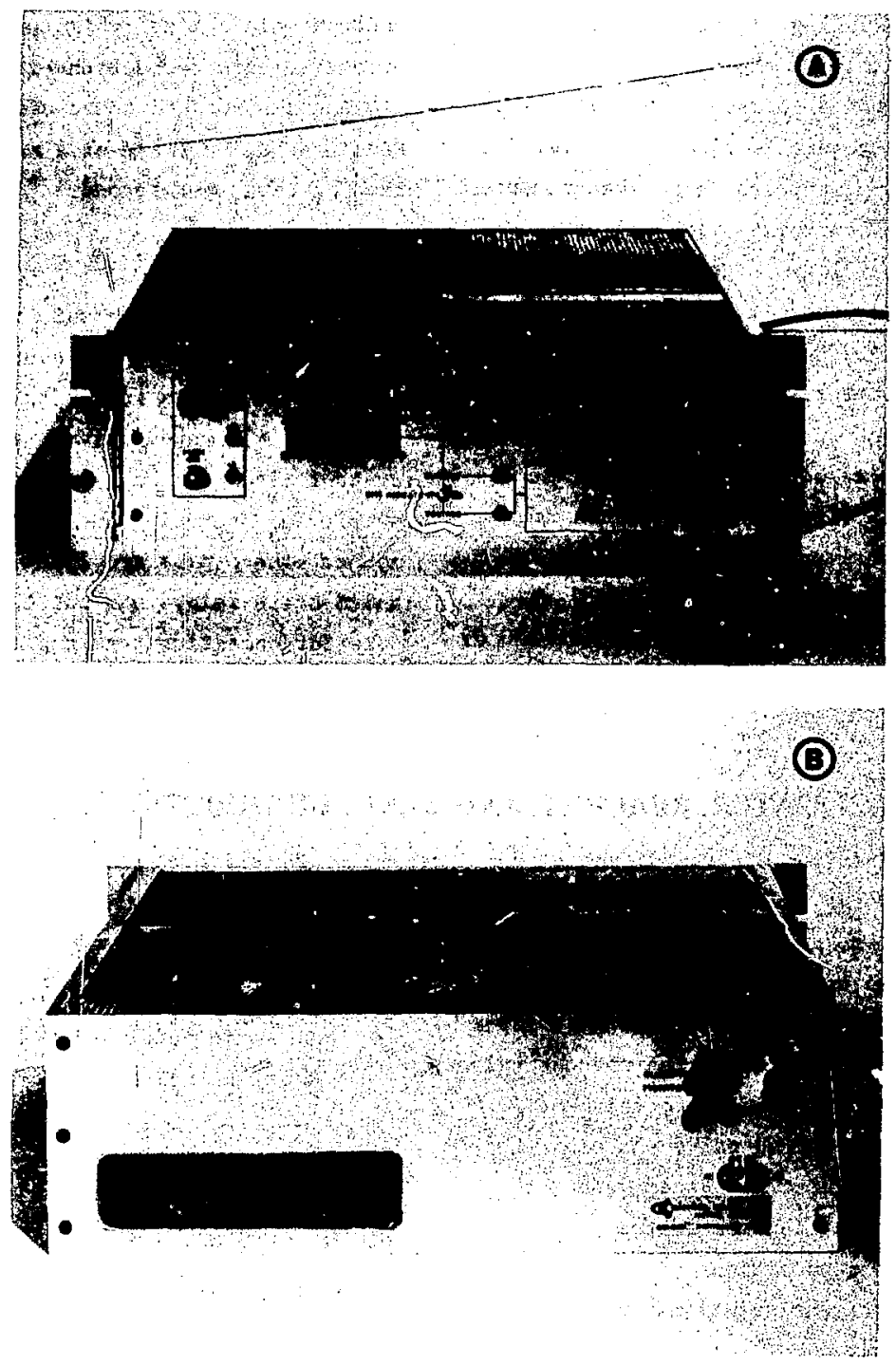

Fig. 14. Programmable constant-current source, front (a) and rear (b) panels. 
for measuring and transmitting, to the computer, the generator and Indicator electrode potentials va a single reference electrode (FIg. 15). Switching between these measurements can be controlled manually or by external logic siguals. The heart of this module is an Analog Devices mode1 AD2004, 4-1/2-d1g1t digita1 panel meter. This meter Indicates voltages in the range of $\pm 1.9999 \mathrm{~V}$ wth a resolution of $0.1 \mathrm{mV}$. It has a fully floating differential input wth an Impedance of more than $100 \mathrm{M}$, a blas current of less than $1 \mathrm{nA}$, and a common mode rejection of $120 \mathrm{~dB}$ at $60 \mathrm{~Hz}$. The analog and digital sections are optically 1solated. Automatic zero correction circultry compensates for drift and offset. Readings can be taken at a maximum rate of elght per secorid.

\section{VALTE DRIVER CHASSIS}

The valve driver chassis (F1g. 11, below the control panel) contains solld-state relays for switshing power to the system valves, the control circuit, and the dc power supply for operating the stirring motor. There also are $117-\mathrm{V}$ ac solld-state relays and switched outputs for operating the sample changer and a water-pressure booster pump.

\section{GAS, WATER, REAGENT, AND WASTE DISTRIBUTION SYSTEMS}

A detalled diagram of the flow system for the distribution of reagent solution, gas, water, and waste solution to and from the titration cell is given In FIg. 16. The most important components are the reagent valve system, the reagent containment sys tem, the gas valve chassis, the water regulation system, and the waste distribution system.

The compositions of the pretitration reagent solutions ${ }^{6}$ are as followe:

- Reagent 1: $1.5 \underline{\mathrm{M}}$ sulfamic actd.

- Reagent 2: $0.11 \underline{\mathrm{M}}$ ferrous sulfate, $13.3 \mathrm{M} \mathrm{H}_{3} \mathrm{PO}_{4}$, and approxtmacely $0.001 \%$ chromium from the preoxidation of the $\mathrm{H}_{3} \mathrm{PO}_{4}$ wth $\mathrm{K}_{2} \mathrm{Cr}_{2} \mathrm{O}_{7}$.

- Reagent 3: $8.0 \mathrm{M} \mathrm{HNO}_{3}, 0.15 \mathrm{M}$ sulfamic acid, and $0.4 \%$ ammonium molybdate.

- Diluent: $0.3 \underline{\mathrm{M} \mathrm{H}}_{2} \mathrm{SO}_{4}$ and $0.025 \underline{M}$ voso $_{4}$.

\section{REAGENT DELIVERY SYSTEM}

The heart of the pretitration reagent delivery system is a sixposition reagent selector valve (V5, Laboratory Data Control No. R6060V6AP-K). The valve Is switched through its six positions during the 
()
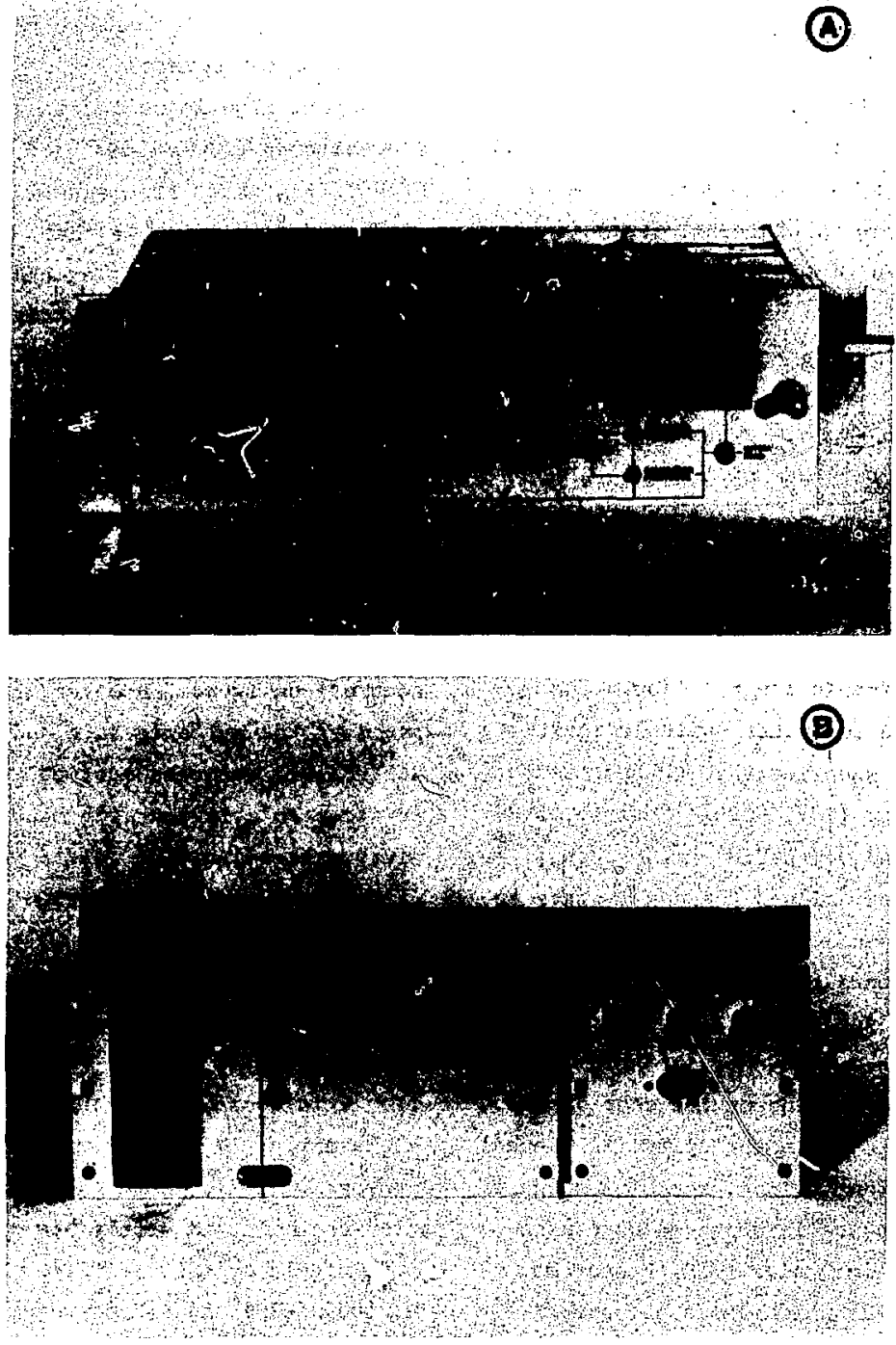

FIg. 15. Electrode potentlal measurement interface, front (a) and rear (b) panels. 
course of the pretitration operations to deliver the appropriate reagent solutions to the cell. The quantity of each resgent is determined by the solution flow rates and by the length of time the reagent delivery valve (v3, Altex No, 201-03-Tefze1) is open. Valves 76 to v9 (three-way, Altex No. 201-04-Tefze1) are used to open their respective reagent 1 ines to water to flush the system downotream. Valves V3, V5, and V6-V9 have a zero deadvolume, a 1.6-min bore, and are pneumatically operated.

As shown in FIgs, 10 and 16, the reagent containers are pressurized to $80 \mathrm{kPa}$ (12 psi) with nitrogen gas to enable reagent flow. The nitrogen (or other sultable inert gas) is supplied through a pressure regulator (PCV, Circle Seal No. PVR3-PM) and valve V10 which, when energlzed, allows the gas to pass to the reagent contalners. The V10 valve vents the gas and hence relleves the reagent pressure whenever it is deliberately de-energized or, via an interlock, whenever the door of the reagent contalnment system is opened. Protection against excessive reagent gas pressure 18 provided by a pressure rellef valve (PSV, Valcor No. 101T34-72) which vents at approximately $100 \mathrm{kPa}$ (about $15 \mathrm{psi}$ ). Sma11 deviations $(0.7 \mathrm{kPa})$ in pressure that affect the accuracy of reagent delivery are monttored with a pressure switch and gage (PSI, ACCO-Helicold tỹye IDC) which has both high and low adjustable set points.

Reagent flow 18 monitored with flowaw1 tches (FS, Valcox No. SV400T2HF), which are magnetically activated re ad swteches that close when the solition flows exceed preset levels. Each reagent lint also contains a check valve (CV, Mace No. CV2-23) that prevents reverse flow of the reagents when the oystem 18 depressurized.

Unrestricted flow at the driving pressure is allowed for the $\mathrm{Fe}(\mathrm{II})-$ $\mathrm{H}_{3} \mathrm{PO}_{4}$ and diluent reagents because these flow rates are satisfactory for accurate delivery. However, the flow rates of the sulfanic acid and $\mathrm{HNO}_{3}-\mathrm{MO}$ (VI) reagents must be reduced to acceptable levels with manual, micrometer-adjustment needle valves (V18 and V19, Gilmont micrometrictype).

Position 5 of V5 is supplied with water from the water mantfold via the manual throttling valve (V20). Pos1tion 6 is connected to the source of clean alr at $14 \mathrm{kPa}$ (about $2 \mathrm{ps}$ ) of pressure. This, in turn, is taken from the main air supply via a pressure regulator (PCV, veriflow No. HIR1005250PM) and a flow-regulating manual needle valve (V27). If the air pressure should exceed $35 \mathrm{kPa}$ (5 psi), the safety valve (PSV, Codecal No. 1000-2) closes to protect the down- 


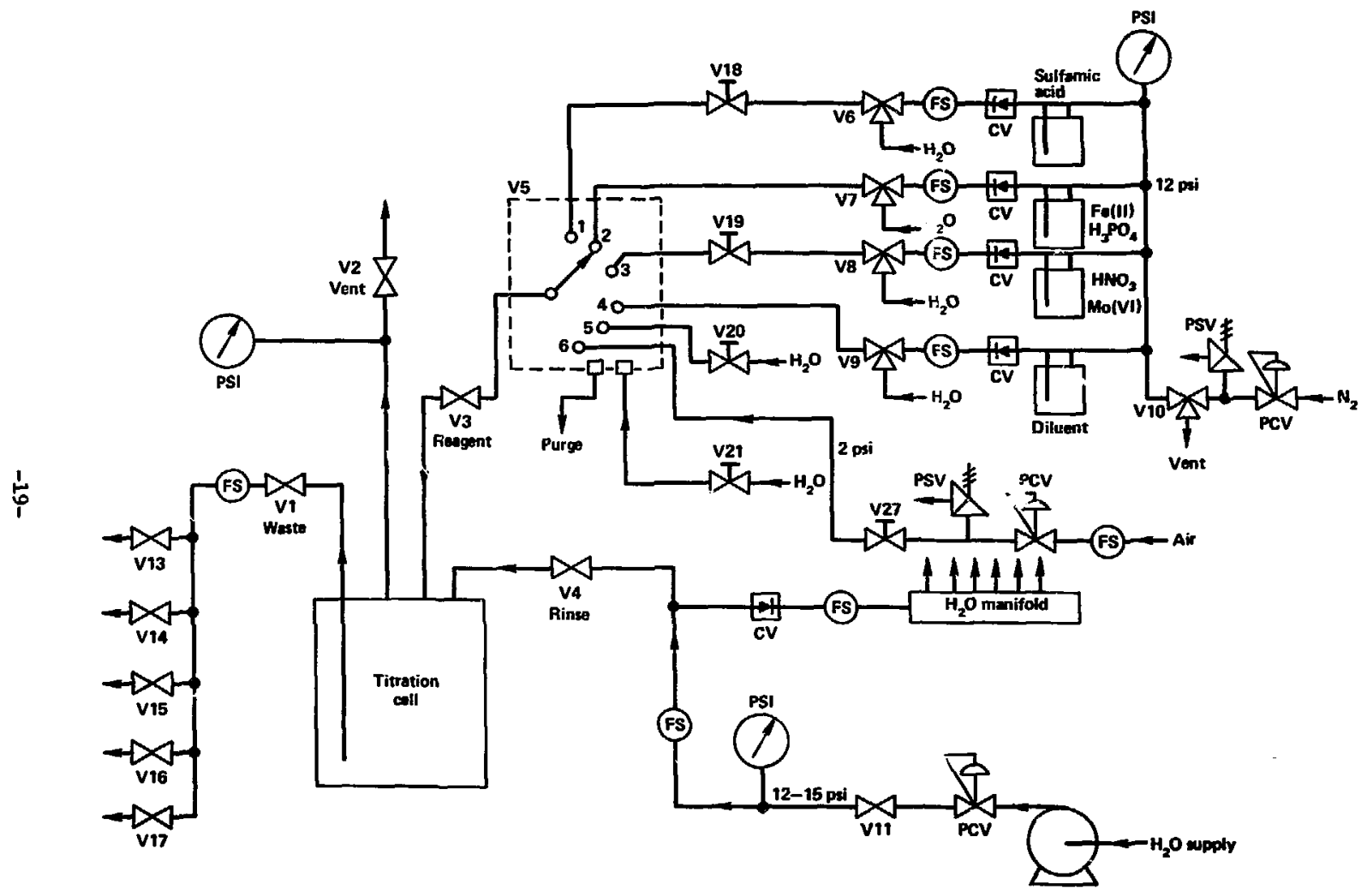

FIg. 16. Solutions, gas, water, and waste distribution system (CV = check valve, FS = flowswitch, PCV = pressure regulator, PSV = pressure rellef valve, and PSI = pressure switch/gage). 
stream apparatus. The supply air is switched on and off with a solenoidoperated valve (V12, not shown). A stiall trickle of water also is supplied to valve v5 to purge certain Inside passages and to prevent the formation of crystals of solld materlal from the reagent solutions; this Is accomplished with manual valve V21.

All materials that directly contact the reagent solutions are either glass or fluorocarbon plastlc. Whenever possible, all other components in the analytical system that may contact corrosive vapors also are fabricated from Inert plastics or from otainless steel. Valves V1-V9, together with the associated tubing and fittings, are assembled in a polyethylene box (FIg. 17) that is supported on the sample changer near the titration stacion.
REAGENT CONTAINMENT SYSTEM

Four glass reservolrs, one for each reagent, are housed in a polycarbonate and polyethylene plastic enclosure (F1g. 18). The reagent contalners are fabricated from 15-cmId glass process pipe rated at $207 \mathrm{kPa}$ (30 pa1). The capacity of the Fe(II)$\mathrm{H}_{3} \mathrm{PO}_{4}$ container $1 \mathrm{~s}$ about $7 \mathrm{dm}^{3}$; the capaclty of the other contalners is about $15 \mathrm{dm}^{3}$. These quantities are sufficient for at least 100 determinations. Tefion screw caps fitted with Teflon-covered o-rings permit easy fllling of the reservolrs (F1g. 18c). The level of solution in the reservolrs is monitored by visual observation through windows in the enclosure.

WATER REGULATION SYSTEM

A deloniz ad or distilled water IIne is connected to the water regu-
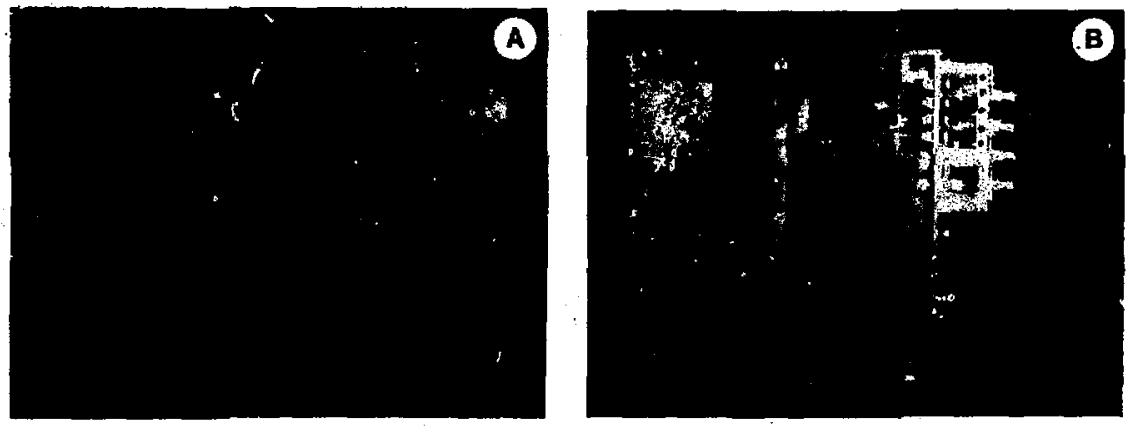

FIg. 17. Reagent valve system, side (a) and top (b) views. 


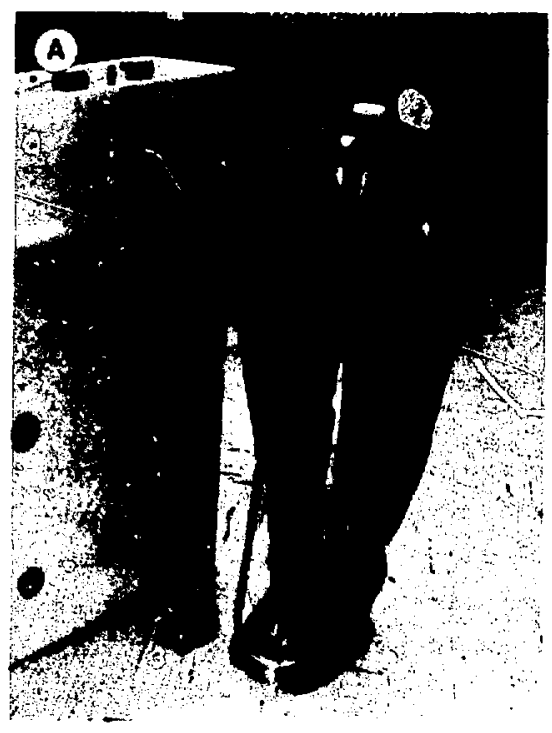

F1g. 18. Solution reservolr (a), and side (b) and top (c) vilews of the reagent containment system enclosure.

lation module (FIg. 19). This unit contains a pump (Micropump model 10-84-316) to boost the pressure (as necessary) to that required for cell rinsing, a pressure regulator (PCV, Valcor No. J.00T32-54), a solenoldoperated shutoff valve (V11), and a
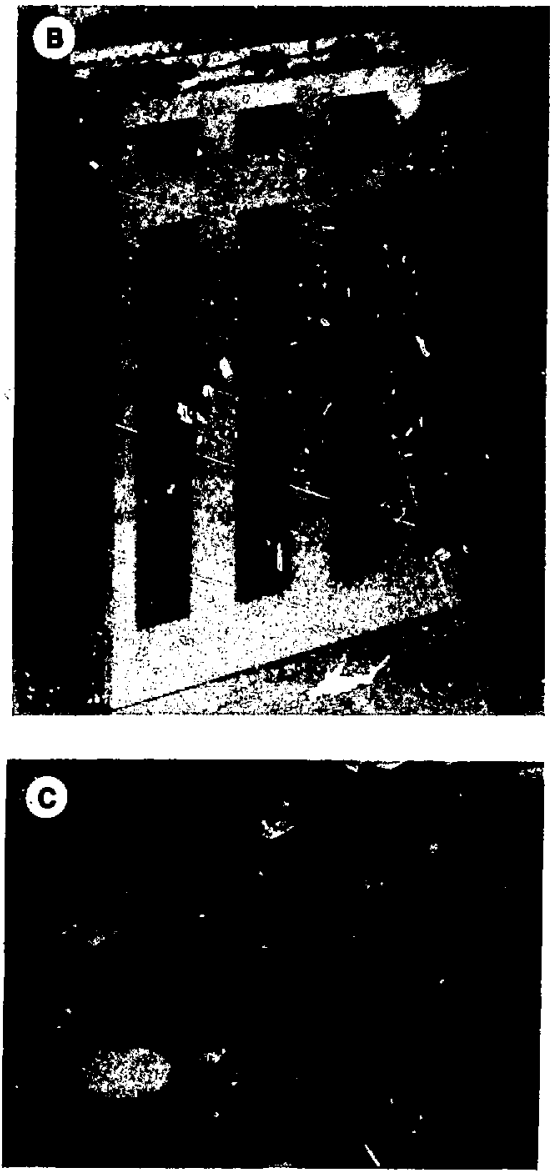

flowsw1tch (FS, Valcor No. SV400T8) to monitor the high flow (about $1 \mathrm{dm}^{3} / \mathrm{min}$ ) during rinse. The no-flow pressure of the water [50 to $100 \mathrm{kPa}$ (7 to $15 \mathrm{psi}$ )] is monitored with a dual set-point pressure switch and gage (PSI, ACCO-Hellcold type IDC). 


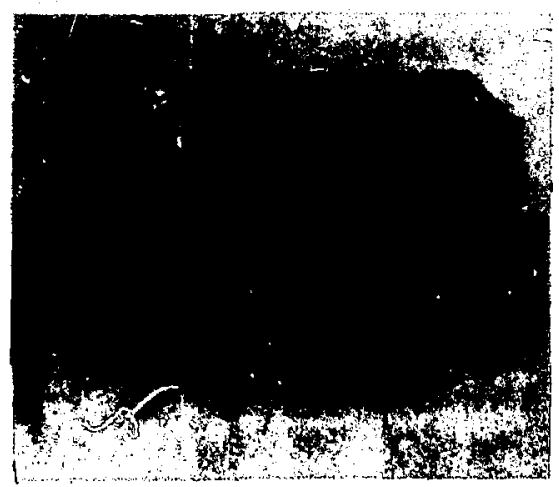

F18. 19. Front pand of the water regulation ayatem.

Within the reagent valve syatem, water 1s routed via a manifold (FIg. 16), a check valve (CV, Mace CV2-34), and a second water flowswltch (FS, Valcor No. SV400T2) to monitor the flow of water to position 5 of valve V5.

\section{WASTE DISTRIBUTION SYSTEM}

This module (FIg. 20) is a manifold of five low-cost (Noryl plastic body) solenold-operated valves (V13V17, Skinner No. V426DAO-JV011). The valves are programmed to route the waste solution from the titration cell into various containers. Waste valve V1, and the flowswitch (FS, Valcor No. SV400T2HF) that reglsters the flow of waste, are located in the reagent valve system module.

\section{gas VALVE chassIS}

The gas valve chasale (FIg. 21) contains filters for purifying the supply air that operates the pneumatic valves and the sample changer. This unit also contalns regulators for the purified air, the cell pressurization gas, and the nitrogen gas for presBurizing the reagent containers, as well as sensors and gages for monttoring the varlous system gas pressures and the flow of the cell gas. The cell gas pressure is measured with an ACCO-Hellcold-type IDC gage/switch (PSI, FIg. 16) connected to the cell vent 1ine. The gas valve chassis also includes $81 x$ solenold-operated four-way valves (Humphrey No. 062-tE1) for switching alr to pneumatic valves v3, v5, and v6-V9. The gas valve chassis, the water regulation chassis, and all of the electronic instrumentation except the minicomputer are housed in the system control console (F1g. 11), a 1.5-m-high double relay rack.

n

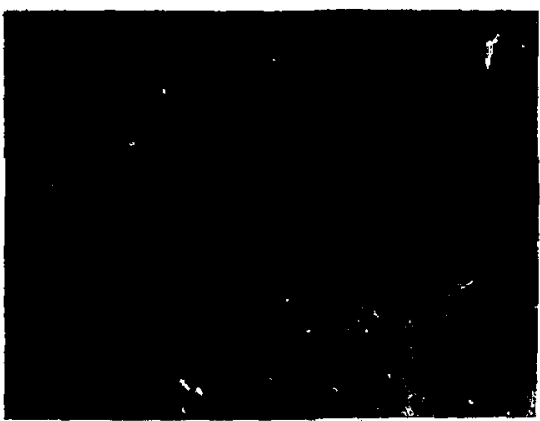

Fig. 20. Waste distribution aystem. 

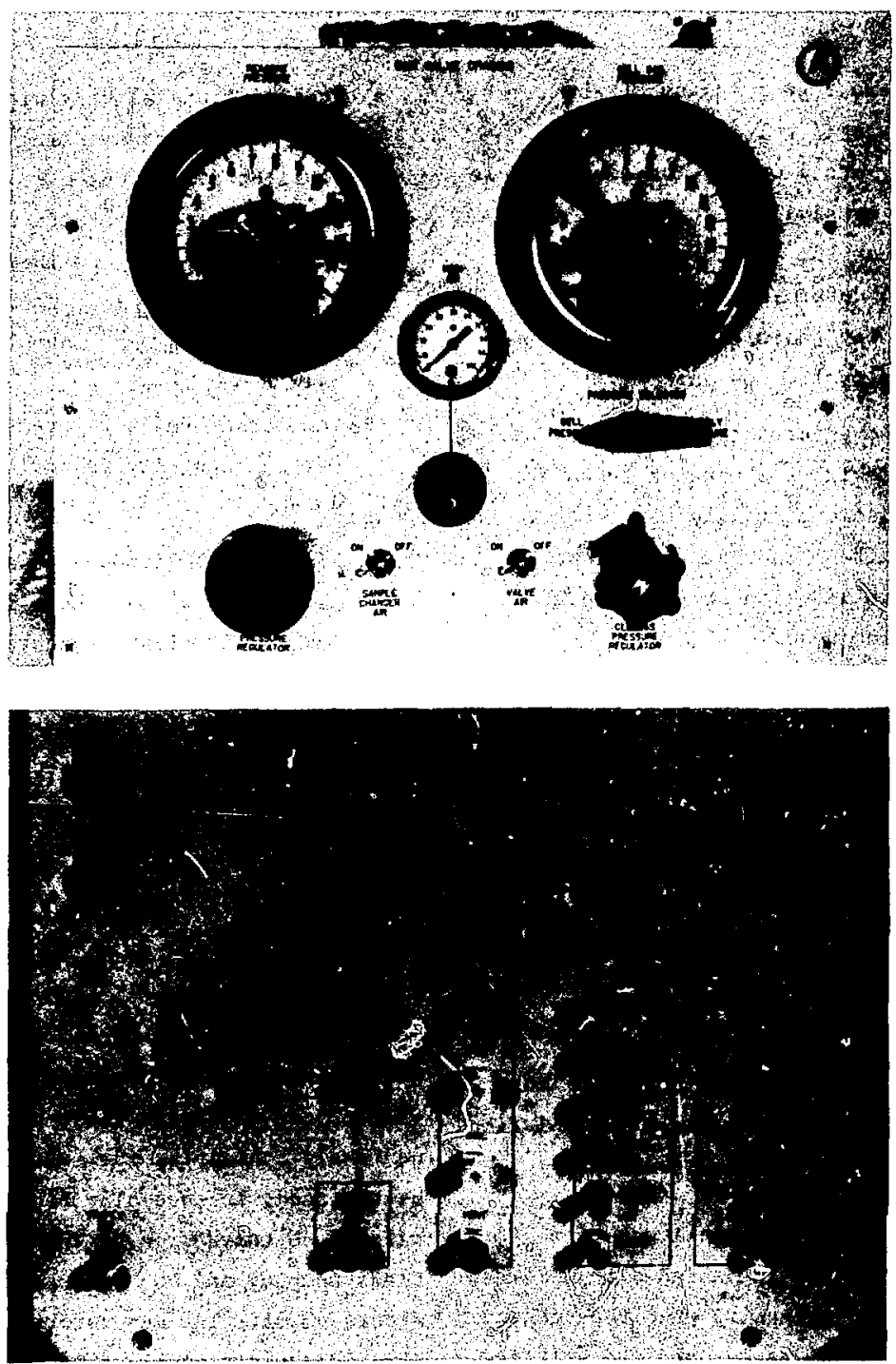

F1g. 21. Gas valve chassis, front (a) and rear (b) panels. 


\section{TITRATION CELL ASSEMBLY}

The exact positioning of the components (e.g., the electrodes, atirrer, etc.) within the electrolysis cell to crucial for the proper functioning of the syotem and for the accurate determination of urantum. Several key features are incorporated Into the system design:

- The generator and counterelectrode separator tubes are placed coaxially to create a untform current and potential distribution at the generator electrode.

- The indicator electrode and the reference electrode salt-bridge junction are located outside the principal current-flow path on an equipotential line; thus thece is minimum interference with the potential measurement by the current flow.

- Al1 four of the electrode assemblies are located so that they do not contact the solution during the pretitration.

- The solution delivery-tube assembly is designed to eltminate splashing when the reagents are delivered, and the stirring Impeller is designed to give maximum stirring without splashIng.
- The solution-dellvery wire, waste tube, and stirring Impeller are oriented so that they do not contact the new sample solution when the beaker Is first ralsed into position, thus ensuring that, should the sample not be processed because the beaker falls to pressurlze, sample Integrity is not breached.

- Finally, all components are assembled so that there is a reasonably tIght pressure seal within the cell when the titration beaker is in place. Thus the cell is pressurized to signal the start of the pretitration and to dispose of the spent titration solution through the waste tube.

A diagram of the titration cell designed to meet these criteria is shown In Fig. 22. The glass beaker (F1g. 23a), enclosing these components and containing the solution to be titrated, is specially fabricated with close tolerances by the Wilmad Glass Company and hes a capacity of about $300 \mathrm{ml}$. The generator electrode (F1g. 23a) is a double-thIckness (F1g. 22) of expanded gold (Exmet No. 8AU10-5/0), affixed to a 2-im-diameter platinum rod. It may be possiole to 


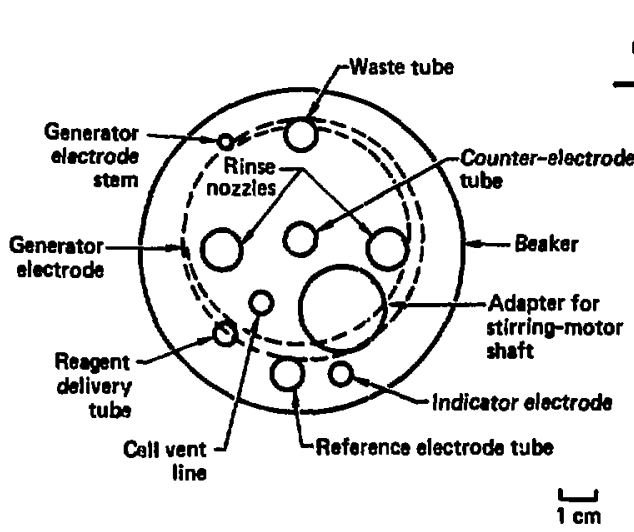

Top view

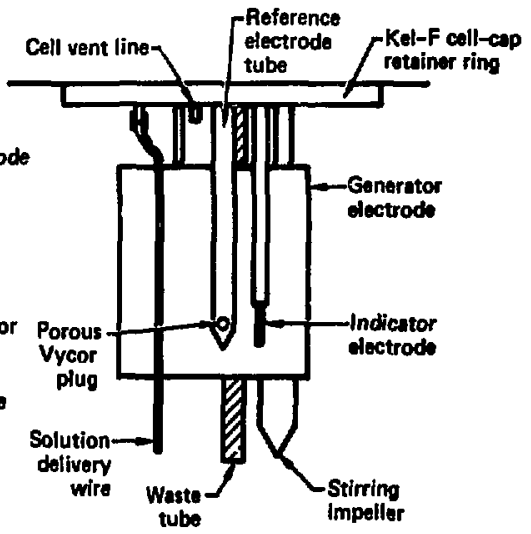

Side view

FIg. 22, Titration cell assembly.

use platinun gauze. However, exper1ments at the New Brunswick Laboratory ${ }^{16}$ and preliminary studies conducted at LLL have revealed that negative errors in the titration then result, apparently because of a catalytic oxidation of the U(IV). The counter electrode (Fig. 23b) is a spiral of platinum wire that is enclosed in a tube, the lower section of which is either porous Vycor (Corning Glass No. 7930) or a Nafion (DuPont) 1on-exchange membrane. 17 Both 1-mm wire gold and platinum Indicator electrodes (FIg. 23c) have been used, the former sealed in heatshrinkable Teflon and the latter sealed in glass or used bare. The reference electrode, a Radiometer type $\mathrm{K} 601 \mathrm{Hg}-\mathrm{Hg}_{2} \mathrm{SO}_{4}$ electrode, is held above the cell in a tube that is connected to the salt-bridge tube (F1g. 23c). The salt-bridge tube 1s Kel-F with a force-fitted plece of porous Vycor rod as the solution function which is ortented (FIg. 22) away from the generator electrode.

Reagent solutions are delfvered from valve $v 3$ to the cell through 3.2-mm-od Teflon tubing, to which is attached a gold wire (FIg. 23d). This wire eliminates splashing of the dense, viscous $\mathrm{Fe}$ (II) $-\mathrm{H}_{3} \mathrm{PO}_{4}$ solution upon delivery. In addition, the flow rates of the $\mathrm{Fe}(\mathrm{II})-\mathrm{H}_{3} \mathrm{PO}_{4}$ and $\mathrm{HNO}_{3}-$ Mo(VI) solutions are adjusted so that they flow down the wire, thus ensuring that no $\mathrm{Fe}$ (II) remalns unoxidized by the $\mathrm{HNO}_{3}$. The waste and vent tubes are $6-$ and 3.2-mm-od Teflon tubes, respectively (Fig. 23d). The glass stirring Impeller (Fig. 23c) is 

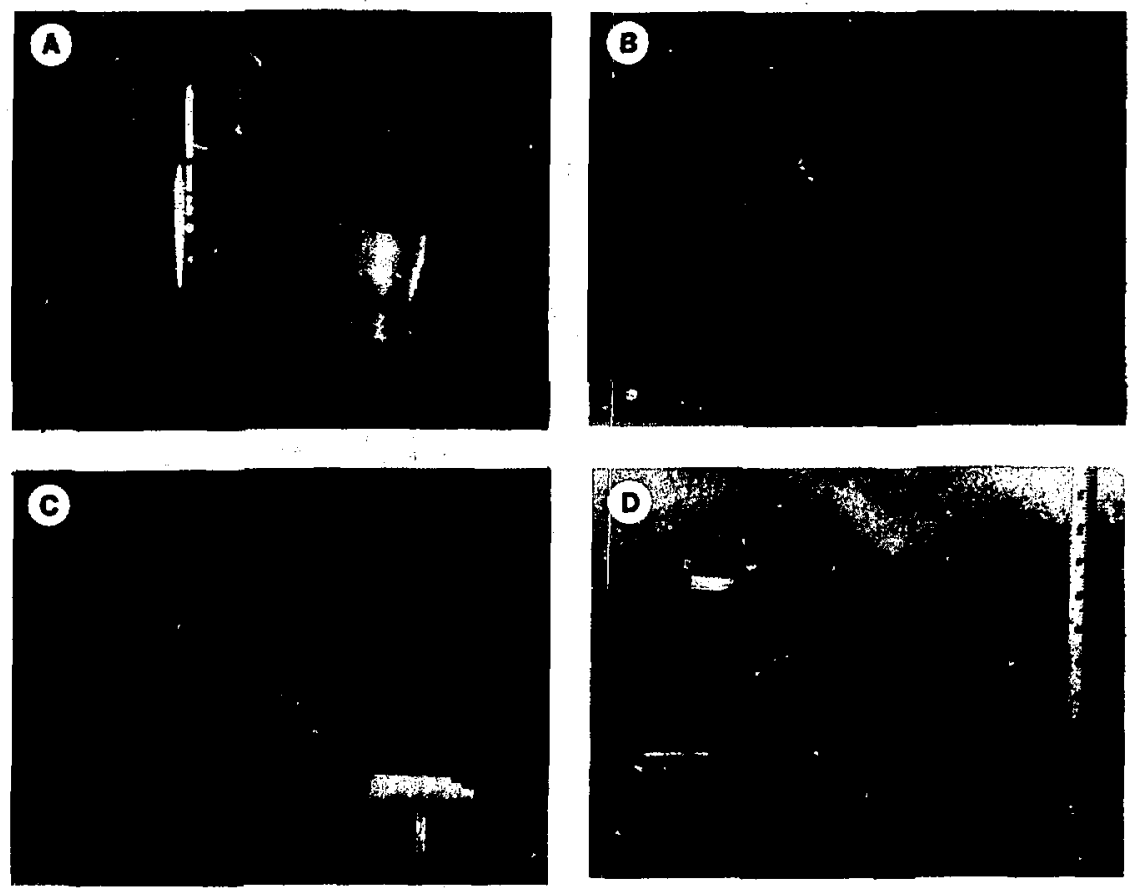

F1g. 23. Titration cell components. From left to right in (a), beaker and generator electrode; from top to bottom in (b), counter electrode and separator tube; from top to bottom in (c), indicator electrode, salt-bridge tube, and reference electrode; and from bottom to top in (d), stirrer, waste tube, and dellvery tube.

a flat blade, approximately 2 min thick, about the same height as the generator electrode and tapered at the end. The Impeller is rotated by a $12-V$ dc tachometer-feedback, speed-regulated motor (Barber-CoIman No. FYQM-63260). The motor and the Kel-F coupling shaft are contained in a hermetically sealed enclosure. Three states - off, low speed (about $1300 \mathrm{rpm}$ ), or high speed (about $3600 \mathrm{rpm}$ ) - can be selected manually or by the computer program. The cell components are rinsed by a spray of water from two Teflon Bete-Fog (120 deg) full-cone spray nozzles mounted in the cell cap.

The titration cell assembly is mounted as shown in Fig. 24 on a spectal Kel-F platform at station No. 4 of the sample changer. When 


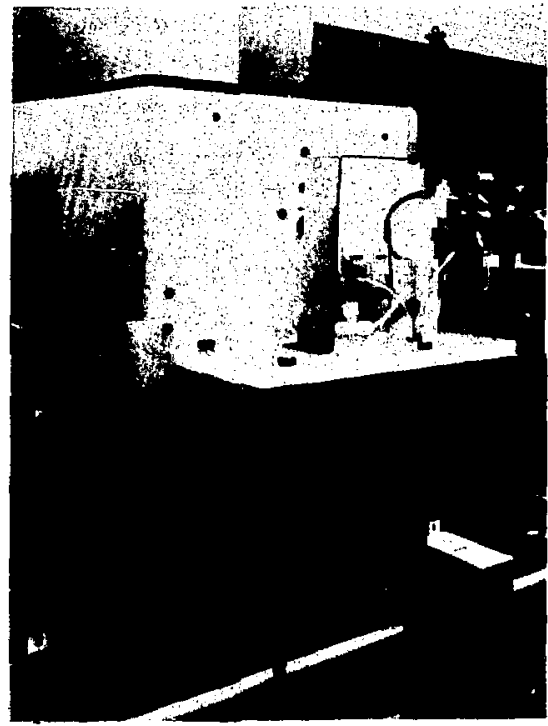

Fig. 24. Titration station. the beaker is ralsed, its rim presses against an Inert Viton elastomer gasket in the cell cap to create the pressure seal. A polycarbonateplastic cylindrical enclosure around the cell components serves as a safety shield and protects the components from damage in the event of misalignment in the ralsing of the beaker.

\section{SOFTWARE DESCRIPTION}

The system software is designed to Interact with the operator and electronic balance for the acquisition and storage of sample ID and weight information. Interactive software allows the operator to specify the titration conditions. The software also controls the uechanical operations of sample queulng, pretitration reagent addition, post-titration solution disposal, and cell rinsing. The instruments for regulating the electrolysis curfent, acquiring the titration data, and reading the coded sample position labels are all controlled by systems software. In addition, software routines process the titration data to obtain the analytical results and output the analysis reports. System software also monitors the fault-detection circults, detects abnormal analysis conditions, and when faults and errors arlse, carries out preprogrammed actions and generates specifled error messages.

The basic software was witten to be used with a modifled version of 
the Digital Equipment Corporation Interpret1ve language, 8K FOCAL. Two large overlays were written In assembly language to operate with $8 \mathrm{~K}$ FOCAL: NBLWT for handling the welghIng and recording of sample welght and Identification Information, and AUTVAL for most of the other system hardware control functions and faultmonftoring functions except those assoclated with the actual titration.

Two FOCAL user programs were designed for this system. One is the fundamental weighing and titration program for routine operations. The other is a test program which provides several operator-selected options for the analysis cycle, but which does not have the capability of weight information manipulation or calculation. W1th either program, the operator has the option, via the startup dialogue, of conducting the titrations with preset parameter values (e.g., electrolysis current levels, number of data points) or with values selected in response to quertes from the computer. For troubleshooting, the system can be operated by the test program in an automatic mode in which the sample changing as well as the pretitration and post-titration valve sequencing are carried out with water instead of reagent solutions.

Two 4-K segments of core memory are allocated for storage of the sample or standard welghts and ID numbers. Depending on the proportion of standards and samples, there $1 s$ storage capacity for 340 to 1024 entries.

Several spectal function calls were created to be used in commands of the form of $S$ U-FSET( ), S U=FCUR( ), F U=FVAL ( ). These commands then were written Into the user programs to manipulate the welght Information and to control the electronic instrumentation, the timing of the operations, and the sequence of the mechanical operations. For example, certain FVAL( ) arguments can be used to 1ist the welght data storage and to delete entries. The level of the electrolysis current, the sequence of titration-curve data taking, and the timing of the data taking are established by the arguments of FCUR( ) and FSET( ). The states of the 17 valves, the stirring motor and the valve timing are determined by a numerical code in the arguments of a series of FVAL( ) statements. Because these functlons are part of the user program, they can be readily changed under the rules of FOCAL programming. [L1stings of the programs and add1tional information about their operation are available upon requesit from the authors (J. E. Harrar or J. D. Breshears).] 


\section{SEQUENCE OF OPERATIONS FOR AUTOMATED ANALYSIS}

The overall sequence of operations In the analytical cycle is diagrammed In FIg. 7 and the execution of the pretitration and post-titration procedures can be visualized by referring to Fig. 16. During normal sample processing, valves $\mathrm{V} 1 \mathrm{D}, \mathrm{V} 1 \mathrm{l}$, and $\mathrm{V} 12$ remain energlzed to, respectively, pressurize the reagent containers, supply water, and supply alr. Also, valves V6-V9 are switched to the reagent 1ines. To ready the system for the analysis, valves V1, V3, V4, and V13-V17 must be closed, V2 must be open, VS must be allgned at positIon 6 , and valves V6-V12 must be configured as described above.

\section{BETWEEN-SAMPIE PERIOD}

To start the sample processing, the operator types the letter $T$ on the teletypewriter. This commands the sample changer to advance the magazines containing the sample beakers. Typing $\mathrm{T}$ also causes the cell vent valve (V2) to close and the reagent delivery valve (V3) to open. The reagent selector valve (V5) is at position 6 and thus when v3 is opened, alr at $14 \mathrm{kPa}$ (about $2 \mathrm{psI}$ ) flows out of the reagent dellvery tube at the titration station. Valve $\mathrm{V} 2$ 1s closed; thus, when a beaker is brought to the titration station, lifted and pressed against the gasket, and a good seal ts formed, $14 \mathrm{kPa}$ of pressure quickly develops In the beaker. This increase in pressure is detected by the cell pressure switch and serves as the pnematic signal that a beaker is in place, ready for sample processing. Verification of beaker pressurization In this manner also ensures that during the post-titration, solution disposal by cell pressurization will function properly.

\section{PRETITRATION}

The pretitration sequence begins as soon as the cell pressurization signal is recelved. The cell vent valve (V2) is reopened, the stirrer Is turned on at low speed, the reagent dellvery valve (V3) 18 closed, and the reagent selector valve (V5) is advanced to position 1 . After $2 \mathrm{~s}$ to permit the operation of V5, the reagent delivery valve is opened for about $4 \mathrm{~s}$ to allow $5 \mathrm{~cm}^{3}$ of sulfamic acid to flow into the beaker. In a similar manner, $45 \mathrm{~cm}^{3}$ of $\mathrm{Fe}$ (II)$\mathrm{H}_{3} \mathrm{PO}_{4}$ solution is delivered at position 2. A 30-s delay then occurs to allow the reduction of $U(V I)$ to U(IV). Next, $10 \mathrm{~cm}^{3}$ of the $\mathrm{HNO}_{3}-$ Mo(VI) reagent is dellvered at position 3, followed by a 3-min delay to 
permit complete oxidation of the excess $\mathrm{Fe}(\mathrm{II})$. Then, $160 \mathrm{~cm}^{3}$ of diluent is added, after which the stirrer is switched to high speed. At position 5 of V5, about $5 \mathrm{~cm}^{3}$ of water is delfvered in approximately $2 \mathrm{~s}$ to flush the diluent out of the line, leaving it clean for the next sample. As the reagent delivery valve is closed and V5 1.8 advanced to position 6, the signal is given to atart the titration.

\section{TITRATION}

No switching of valves occurs during the titration period except when a fault condition is detected. However, it is possible to use an Inert-gas blanket over the solution during the titration, by merely substituting the inert gas for the alr at position 6 of V5 and by keeping $\mathrm{V} 3$ open.

Flgure 25 illustrates the sequence of data acquisition and current control in the coulometric titration. Before the start of electrolysis, a measurement $1 \mathrm{~s}$ made of the openclrcuit generator electrode potential vs the reference electrode and of the indicator electrode potential vs the reference electrode. These data are stored for later readout with the titration results (see Figs. 8 and 9), which is accomplished by the electrodepotentlal-measurement Interface. The programmable constant-current source then is switched to the reaction cell and electrolysis begins at $300 \mathrm{~mA}$ (I1, Fig. 25).

Data acquisition continues with 1-s Intervals between measurements of

\section{Time $\longrightarrow$}

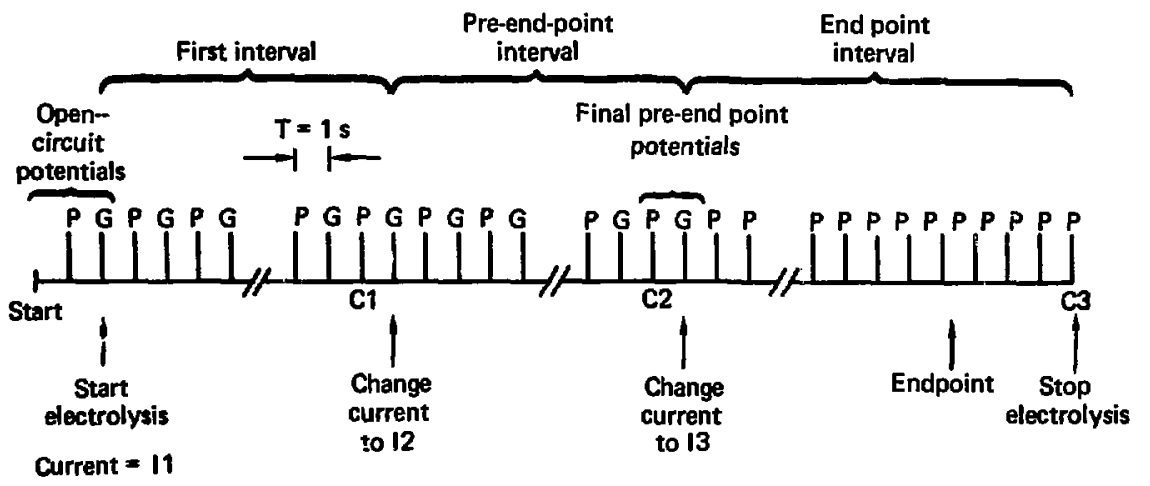

F1g. 25. Titration data acquisition and current control scheme ( $P$ Indicator electrode potential, $G$ = generator electrode potential). 
the indicator and generator electrode potentials. After each measurement of the Indicator electrode potential, the data are smoothed using an algorfthm that is the digital-filter equivalent of an analog, single-pole, RC filter. The equation is ${ }^{18}$

$$
Y(t)=(1-\alpha) X(t)+\alpha Y(t-1)
$$

where $Y(t)$ is the output of the filter (the calculated smoothed polnt), $X(t)$ is the Input or most recent data point, $Y(t-1)$ is the previous f1lter output, and $\alpha$ is a coefficlent selected to obtain a particular time constant or degree of smoothing. The value of $\alpha$ is given by

$$
\alpha=e^{-1 / n}
$$

where Ii is the number of data points corresponding to the desired time constant. In the titration system, we use $\alpha=0.81873$. Th1s is equivalent to a time constant of 5 data points or $10 \mathrm{~s}$ for the 2-s Interval sampling of the Indicator electrode potential. The most recent data point is then subtracted from the previously smoothed point. This difference in volts is divided by the difference in coulombs corresponding to the two data points to obtain the slope of the curve $(\mathrm{V} / \mathrm{C})$.

The calculated slope is compared with a value of $+0.0001 \mathrm{~V} / \mathrm{C}$; when this Is exceeded, a calculation is made to determine whether $21 \mathrm{c}$ of electrictty (Q) have been passed. If so, a quantity of urantum in the sample greater than approximately $50 \mathrm{mg}$ is indicated and no action is taken. If $Q$ 1s less than $21 \mathrm{C}$, a quantity of uranium less than about $50 \mathrm{mg}$ is Indicated and the current is reduced to $100 \mathrm{~mA}$ (I2, FIg. 25) so the end point w111 not be approached too rapidly. Such a sample is designated a "Small Sample" in the data readout (see Fig. 8). Smoothing and slope calculation then continue unt1l the indicator-electrode potentlal begins to change rapldly. When a preset value of "Pre-Endpoint Slope" is exceeded, the electrolysis current is reduced to $10 \mathrm{~mA}$ (I3, FIg. 25), and measurements are taken only of the Indicator-electrode potentials. These data in the end-point interval are processed later to locate the end point in the titration. In the endpoint interval, the titration is continued past the inflection point of the curve until the slope of the curve drops below a preset value.

During each cycle of data acquisition, several conditions of the titration are monttored by the FOCAL program. After each reading of the indicator electrode potential, the actual electrolysis current is measured and compared with the nominal current to determine whether $1 t$ is within a tolerable error band. Also, 
the total quantity of electricity passed Is not allowed to exceed $150 \mathrm{C}$. Thus after each reading of the generator electrode potentlal, the value is compared with an allowable upper positive 1imit. In addition, the total output voltage of the constantcurrent source is measured during each data cycle and is not allowed to exceed the compliance 1imit of $45 \mathrm{~V}$. Should any of these fault conditions occur, the titration is terminated, the post-titration sequence is initiated, and approprlate error messages are printed out.

\section{POST-TITRATION}

Upon termination of a nornal titration, the data are held in memory for processing after the posttitration operations are executed. Th1s sequence begins by opening the reagent delivery valve (V3) to reintroduce air in the system, closing the cell vent valve (V2), as well as opening the waste valve (V1) and the approprlate waste category valve (V12-V17). In about $30 \mathrm{~s}$, al1 the spent solution from the titration is forced out of the cell into a waste container. Then, the rinse valve (v4) Is opened for $5 \mathrm{~s}$ and the cell components are sprayed with water. A 5-s delay for drainage occurs and the cell components are sprayed again for $5 \mathrm{~s}$. During the rinse periods, the beaker is still pressurized so that the rinse solution flows out as waste.

\section{CALCULATION AND READOUT}

After the second rinse, the near $1 y$ empty sample beaker remains in position at the titration station. The titration daca are processed to locate the inflection point in the curve, the end point It calculated, and the titration information is printed out. The Indicator-electrode potential data in the end-point interval are first smoothed with a ten-point moving average to reduce the notse even further. Then, successive differences using the averages are calculated, and the maximum difference (peak) in the first derivative of the titration curve is found. This is the preIimInary estimate of the end point.

W1 th the estimated end point, the original data are convolved with a 9-point Savitsky-Golay function ${ }^{19}$ to yield the second derivative of the data. The Savitsky-Golay algorithm midpoint is started 15 points before the estimated endpoint; the computation is continued for 30 points with 10 data points between each point of the convolute. The result of the Saviteky-Golay convolution is a set of data with values ranging from positive to negative. The zero-crossing corresponds to the inflection point in the original data. To locate this 
zero-crossing, 13 points that encompass the zero-crossing are taken, a least-squares-line equation is found for the 13 points, and the value of the abscissa is computed from the zero of this equation.

After the end point is determined, the quantity of electricity (in coulombs) corresponding to this end point and the quantity of urantum (In milligrams) are computed. This Is accomplished by computing the sum

$$
Q=\sum_{1}^{n} 1_{n} t_{n}
$$

where $I_{n}$ is the current level and $t_{n}$ is the time duration of current flow, both in the nth Interval. Normal readouts of titration data are shown In Figs. 8 and 9. In these outputs,
$C 1, C 2$, and $C 3$ refer to the total numbers of points taken at the ends of the various titration intervals (see FIg. 25) and E.P.= denates the Interpolated end point in numbers of points. Approximately 30 \& are required to process the data and print out the results.

\section{RETURN TO BETWEEN-SAMPLE PERIOD}

If the analysis continues to function properly and accurate results are obtained, the waste valves are closed, allowing the pressure in the cell to Increase. This signals the sample changer to lower the old beaker and bring a new one to the titration station. The valves return to the configuration described for the first between-sample perlod, and the system continues with the next sample.

\section{FAULT-MONITORING SYSTEM}

The uranium analyzer incorporates a comprehensive fault-monttoring system based both on hardware- and software-sensing mechanisms. The faults which can be detected during automatic operation and the system actiun that is taken when a fault is detected are summarized In F1g. 26. The messages that are printed out are shown In upper-case letters.

The fault monitoring scheme coordinates the shutdown procedure, if any, to the status of the system when the fault occurred. Thus only catastrophic conditions such as solution spills justify an emergency stop or a complete shutdown similar to the power-off configuration. Actions for faults that do not affect the sample currently in process (e.g., low reagent pressure during titration) are postponed unt1l the sample analysis is complete. If a noncatastrophic fault occurs when at least 
Fwult/MESSAGE

SAMPLE CHANGER SPILL
REAGENT CONT. SYS. SPILL
REAGENT VALVE SYS. SPIL.
SULFAMIC ACID FLON
PHOSPHORIC ACID FLOW
NITRIC ACID FLOW
DILUENT FLOW
WATER FLOW
RINSE WATER FLOW

CELL GAS FLOW

WASTE FLOW

NO SULFAMIC ACID FLON

NO PHOSPHORIC ACID FLOW NO NITAIC ACID FLOW NO DILUENT FLOW

NO WATER FLOW
NO CELL GAS FLOW
NOWASTE FLOW.
NO RINSE FLON

FIGH REAGENT PRES. LOW REAGENT PAES.

HIGH CELL PAES. LOW AIR PRES. HIGH WATER PAES.

LOW WATER PRES.

NO SAMPLE POSITION NO. LOW BEAKER PAES.

TELECTROLYSIS CURRENT ERROR

Current SOURCE VOLTage LIMIT

HIGH GENERATOR ELECTRODE POTENTIAL

SANPLE TOO LARGE or initial slopes not dotected EPMI or PCCS METER OVEALOAD

Trouble in colculation of titration curve end point CONTAOLSTANDARDERROA Computer POWER FAILURE
Systiom

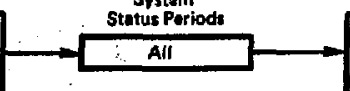

Actiona and additional MESSAGES

Emergency stop ? Feult monitor lemp on

Spill pump outlat on Feult lamp on

Building alarm on

Emergency stop lamp on

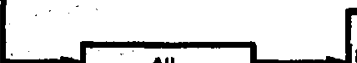

Emergency stop II Feult monitor lemp on

Building alarm on Fult lamp on

Emergency stop lemp on

Continue processing current semple through pout. titration; then HOLD FOR MANUAL RESTART

Faute monitor lamp on

Fault lamp on Building alerm on

Stop procusting; then HOLD FOR MANUAL RESTART

Fault monitor Iamp on

Fault lamp on Building alarm on

Skip to post-titration, executs, then HOLD

FOR MANUAL RESTART

Fault monitor lemp on

Pretitration

Botween-timple 1 Skip to post-titration, execute, then HOLD

pretitration

FOP MANUAL RESTART

Switch PCCS to standby

Stop data loging

Fault Ismp on

Building warm on

Calculate approxlmate and point using beckup routine.

Fead out:

INSUFF. PTS. <E.P. or > E.P.

END POINT BY DIFFEAENCE

or MISSED ENO POINT

End point interval data

Sovitsky-Goley calculation date

Stop processing; then HOLD FOR MANUAL RESTART

Fault lamp on Building alarm on

Stop procetsing; then HOLD FOA MANUAL RESTART

Control stsndard error lamp on

Fault lamp on

Building alarm on

Read out:

LOW BEAKER PRES. \& Position number

Contínue processing; stop and HOLD FOR

MANUAL RESTART when:

NO BEAKER IN 4 TAIES, or

NO MAGAZINE in 60 SECONOS

Foult lamp on

Building alarm on

When power restored, do emergency stop and HOLD FOR MANUAL RESTART.

Emergency stop lamp on

Foult lamp on

Buildiry atarm on

Save date and do emergency stop on power

failure. When power restored, tum off all

valve pomer, do system resat and continue

with calculation and readout: Then HOLD

FOR MANUAL RESTART

Fault Iamp on Building alarm on

Note: Condition HOLD FOR MANUAL RESTART always has emergericy stop fault-monitoring still enebled.

Fig. 26. Diagram of fault, error message, and action taken for the titration system. 
one reagent has been added to the sample or during the titration 1tself, the sample is presumed to be worthless and the program jumps to the post-titration sequence. This minimizes contact between the titration mixture and the cell components in case the system should remain on hold for a long pertod of time. Similarly, In every Instance where a "hold for manual restert" condition is executed, the system goes to a safe configuratIon where the cell components have been rinsed, the emergency-stop fault monitoring is still enabled, and (In most situations) a beaker is st 111 in position at the titration station. Thus, if a spill or flow fault should subsequently occur while the system already is holding from a previous fault, the emergency-stop routines still can be executed.

Solution spilis are detected by sensing the decrease in open-circult resistance between pairs of wires at the sample-ch.anger titration station and in the reagent container enclosure and a grid in the bottom of the reagent valve enclosure. Both an acctdental flow and a lack of flow when called for by the operating program constitute flow faults. For example, during the pretitration reagent addition, as each step of the progiam is executed, the status of the flowswitches is checked to verify that the proper flows take place.
This feature mitigates the need for solution level detectors in the reagent containers.

Abnormalities in the titration curve resulting from indicator electrode fouling or interferences in the sample may cause difficulties when calculating the end point. Various abnormal situations can arlse, all of which terminate sample processing and generate various combinations of the erfor messages shown in Fig. 26. These faults cause all of the data on the indicator electrode potentials in the end-point interval to be printed out. If no zero-crossing is found in the secondderivative calculation, the quantity of uranium is calculated from the estimated end point obtained from the differencing technique and is so Indicated on the printout. However, the end-point-by-difference also may not be found. Information on the cause of the abnormality is given in messages which state that there were insufficlent numbers of data pointo either before or after the end point. The control standard error routine Is Initlated when the result of a standard solution analysis is outside the allowable control 1imfts. (This tolerance, like all of the softwaredetected faults, can be easily changed In the FOCAL program.)

If a power failure to the computer occurs during calculation and readout, 
a1I necessary data are saved and several pointers are set. Thus when power Is restored, program operation can continue without error; after the data readout, a "hold" is executed. If power fallure occurs in other perlods of system operation, the emergency stop configuration is commanded Immediately when power is restored, because, In most cases, system operation cannot be resumed safely without operator interaction.

\section{PRELIMINARY STUDIES OF SYSTEM PERFORMANCE}

A comprehensive study of several of the factors affecting the automated analysis has been published in Ref. 20; some of the resulti are summarlzed here.

\section{SOLUTION DELIVERY SYSTEM}

No detailed studies have been conducted to determine the allowable varlation in the delivered volumes of the four pretitration reagent solutions. However, previous work on the method in which $\mathrm{K}_{2} \mathrm{Cr}_{2} \mathrm{O}_{7}$ was used as the titrant ${ }^{2,21}$ as well as experience In the present work ${ }^{20}$ indicate that for chemical reasons at least, very close control is not required. For the antomated system, however, varlations in the solution volumes must be restricted so that the mixing characteristics of the solution during the reduction, oxidation, and titration steps are not adversely affected and so that the final total volume of solution in the cell is not markedly changed. Positioning of the solutions during the various stages of the automated analysis also requires that the sample volumes range from approximately 2 to $12 \mathrm{~cm}^{3}$. Thus we have set the following tolerances for the four reagent solutions: sulfamic acid, $5 \pm 1 \mathrm{~cm}^{3}$; Fe(II)$\mathrm{H}_{3} \mathrm{PO}_{4}, 45 \pm 3 \mathrm{~cm}^{3} ; \mathrm{HNO}_{3}-\mathrm{Mo}(\mathrm{VI}), 10 \pm$ $2 \mathrm{~cm}^{3}$; and diluent, $160 \pm 5 \mathrm{~cm}^{3}$.

In the present system, the most Important factor affecting the reproductbility of the solution delivery is the change in flow rates caused by variations in the level (1.e., head) of the solution in the reagent contafners. The pressure of the gas used to pressurize the containers is regulated to within $\pm 2.5 \%$ and the reproducibility of the solution delivery at constant head is within $\pm 1 \% .^{20}$ However, the variation in solution head during normal operation usually is approximately $30 \mathrm{~cm}$ and can be as large as $56 \mathrm{~cm}$ for reagents 1,3 , and 4 . The $56-\mathrm{cm}$ drop in solution level causes a considerable change in the effective pressure (about $7 \%$ for pure water 
and greater for the more dense reagent solutions).

The expected effect of the head change was verifled direct $1 y^{20}$; in addition, the reagent solution flow rates were monitored over a 1.5-y perlod, during which time there were no readjustments of the mechanical components. We found that with a 30-cm head variation, the varfations in delivered volume were: $\pm 0.14 \mathrm{~cm}^{3}$ for sulfamic acid, $\pm 1.4 \mathrm{~cm}^{3}$ for $\mathrm{Fe}(\mathrm{II})-\mathrm{H}_{3} \mathrm{PO}_{4}, \pm 0.34 \mathrm{~cm}^{3}$ for $\mathrm{HNO}_{3}-$ Mo(VI), and $\pm 5.4 \mathrm{~cm}^{3}$ for the diluent. Because these values compare well with th. stated specifications and the rellability of the present delivery system has been excellent, we have seen no need to consider a more elaborace system incorporating flow regulation.

\section{REAGENT SOLUTION PURITY}

The purities of tivo of the reagent solutions, $\mathrm{Fe}$ (II) $-\mathrm{H}_{3} \mathrm{PO}_{4}$ and diluent, are critical to the accuracy and the preclision of the results obtained with this analyzer. In the course of this work, ${ }^{20}$ we discovered that in some lots of reagent-grade concentrated $\mathrm{H}_{3} \mathrm{PO}_{4}$, a substance was present that caused the generator electrode to operate at a higher potential where the current efficiency for the oxidation of $V(I V)$ to $V(V)$ is sigIIficantly lowered. This in turn caused a positive error in the analysis and, in extreme cases, resulted In degradation of the gold electrode. The Identify of the contaminating substance is unknwon; it may be the same material that has caused problems in fuel-cell studies with concentrated $\mathrm{H}_{3} \mathrm{PO}_{4}{ }^{2}$ However, the Benerator electrode potential in the analyzer aystem is closely monitored, enabling contaminated lots of $\mathrm{H}_{3} \mathrm{PO}_{4}$ to be easily detected and avoided.

A potential source of negative error in the urantum determination is the presence of $V(V)$ in the diluent. Vanadium(V) may be present in the voso $_{4} \cdot 2 \mathrm{H}_{2} \mathrm{O}$ salt used to prepare the diluent or it may be produced by afr oxidation of the $V(I V)$ in the diluent solution. We did not detect any $V(V)$ In seven lots of two different sources of VoSO $_{4} \cdot 2 \mathrm{H}_{2} \mathrm{O}$; however, a very slow oxidation of $V(I V)$ by air does occur but can be decreased by Increasing the concentration of acid in the diluent. 20 Thus we minimized the oxidation of $V(I V)$ by making the diluent $0.30 \underline{\mathrm{M}}$ In $\mathrm{H}_{2} \mathrm{SO}_{4}$ and by pressurizIng the reagent containers with nitrogen to prevent contact with air. Pressurlating the reagent containers with an Inert gas also improves the stabllity of the Fe(II) reductant, but afr oxidation of this reagent is quite slow. 
TITRATION TECHNIQUE

Extensive studies were conducted ${ }^{20}$ on the current efficiency of the electrolysis and on the titration efficlency ${ }^{23}$ of this analysis.

Curves of the generator electrode potential as a function of current level, under controlled-current conditions, were obtained in both the presence and absence of U(IV). In addition, measurements were made, using a controlled-potential coulometry, of the background current in the potential region where the generator electrode operates. We found that a considerable fraction of the U(IV), in addition to the V(IV), is directly oxidized early in the titration when the $U(I V)$ concentration is high. Thus the current effictency for $V(V)$ generation is lower than $100 \%$ in the presence of uranium, although the titration efficiency remains close to $100 \%$.

Under the particular electrolysis cell conditions chosen, the background current becomes excessive at a potential of about $+0.75 \mathrm{~V}$ vg the $\mathrm{Hg}-\mathrm{Hg}_{2} \mathrm{SO}_{4}$ reference electrode (approximately $+1.18 \mathrm{~V}$ v SCE). The potentlal of the generator electrode is not constant during the titration; typically it rises from about 0.6 to approximately $0.7 \mathrm{~V}$ v8 $\mathrm{Hg}-\mathrm{Hg}_{2} \mathrm{SO}_{4}$ when analyzing more than $50 \mathrm{mg}$ of uranium. Because of this, and because the background current may not be add1t1ve, the precise effect of the background current on the urantum determination is not known. However, the accuracy of the determination is undoubtedly influenced by the fact that a 6-min electrolysis of a blank solution at $+0.7 \mathrm{~V}$ requires the passage of a charge that is equivalent to $0.20 \mathrm{mg}$ of uranium.

An Important constraint in this analytical method is that after the dilution step, there is a slow oxidation of $v$ (IV). Therefore, the titration must be completed in a minimum time to avold a significant negative error. ${ }^{1-3,16,21}$ on the other hand, If the titration is rapid, there is a danger in overshooting the equivalence point because of either slow chemical reactions or sluggish potentlometric measurement response near the equivalence point. In the ortginal coulon etric method of Goldbeck and Lerner, ${ }^{2}$ the titration was carriedout to a spectfic end-point potential with an intermittent pulsing of the constant current (usually $300 \mathrm{~mA}$, with low duty cycle), beginning at a preset potential that preceded the end point by about $1 \mathrm{~min}$.

In the present system, there is a continuous flow of current, with feedback actuation of current change to decreasing levels as the titration proceeds. To avoid rellance on a 
fixed potential of a reference electrode and on constancy of the end-point potential with varying sample media, the end-point anticipation and current control are based on the slope of the titration curve $(v / C)$, rather than on absolute potentials. To optimize the titration over the complete sample range (approximately 10 to $150 \mathrm{mg}$ urantum) the electrolysis current for small samples (50 mg) differs from that for larger samples. For samples below about $50 \mathrm{mg}$ (detected automat1cally by an early change in slope), the electrolysis current is decreased from 300 to 100 to $10 \mathrm{~mA}$. Larger samples are titrated at two current levels, 300 and $10 \mathrm{~mA}$. The slope detection parameters are selected so that as much of the uranium as possible is titrated as rapidly as possible but without overshooting the end point. The titration control scheme is simflar in principle to that used by previous workers (e.g., Refs. 24 and 25) and in some commercial Instruments except that, In this case, the current levels are discrete and the feedback actuation is controlled by the software.

An analytical method is most useful if it can be designed so that it Involves no systematic error and thus is subject to as few arbitrary parameters as possible, both in operation and in data manipulation. The systematic error is lower if the method can be placed on an absolute bas1s; 1.e., if the calculation of the quantities of analyte is based solely on electrical calibrations of the instrumentation (current and time), which are traceable to National Bureau of Standards calibrations. In theory, the controlled-current coulometric technique accomplishes this goal. However, the method locating the titration end point may introduce olgnificant error. The uranium analyzer was designed to store the titration curve data and to take enough data past the equivalence point so that many means of calculatIng the end point are posstble. ${ }^{26}$ Goldbeck and Lerner ${ }^{3}$ originally eatablished the accuracy of this titration with standard solutions of uranium; the end-point potentlal was determined from the inflection point of the titration. Additional evidence corroborating the validity of this approach was obtained in the present work. 20

We investigated whether there is an intrinsic difference between the inflection point of the titration curve and the equivalence point for this particular titration. Using an equation of Goldman 27 which, except for the Involvement of hydrogen lons In the reaction, is directly applicable, we established that the 1nflection point of the theoretical titrat1on curve is within $0.01 \%$ of the 
true equivalence point for the range of concentrations encountered. 20 The actual experimental titration curves, however, do not exactly conform to the shape predicted by the equation. Nevertheless, there appear to be no oignificant grounds for rejecting the inflection-point technique in favor of another.

COMPARISON OF THE TWO END-POINT CALCULATION TECHNIQUES

The basic technique to locate the titration end point involving the Sav1tsky-Golay algorlthm is supplemented by a routine based on a differencing approach. This backup routine is Initiated automatically if a valid end point is not found with the primary calculation. To determine the accuracy of the differencing technique, we compared the two routines, performing both calculations on the same Bets of "normal" titration data (see Table 1). The difference between the two techniques is very small but the backup routine almost always yields lower results than does the Savitsky-Golay algorithm. Although for these data, the differencing technique is quite adequate, the primary routine should be more reliable in the long run because tt is more immune to nolsy and spurious data.
ACCURACY OF THE CONSTANT-CURRENT SOURCE

Theoretically, one of the advantages of coulometry is that there is no need to frequently standardize the titrant. However, to fully realize this benefit, an extremely stable constant-current source is essentlal. We evaluated the constantcurrent source used in our urantum analyzer and found that the drift in calibration over the 30 - to $500-\mathrm{mA}$ range was less than $0.03 \%$ per year. 14 (The accuracy of the Instrument is based on a National Bureau of Standards traceable $1-\Omega$ resistor with an accuracy specification of $0.01 \%$ ) This performance is quite satisfactory for the aralytical preciston we desire.

Table 1. Comparison of SavitskyGolay and differencing techniques for calculating t1tration end points.

\begin{tabular}{cc}
\multicolumn{2}{c}{ Calculated end polnt, mg uranium } \\
\hline Savitsky-Golay & Differencing \\
\hline 113.140 & 113.115 \\
113.114 & 113.103 \\
113.039 & 113.029 \\
56.639 & 56.625 \\
34.005 & 33.993 \\
\hline
\end{tabular}




\section{EVALUATION BY THE NEW BRUNSWICK LABORATORY}

The automated titration system was designed and bullt for the New Brunswick Laboratory (NBL) of the U.S. Department of Energy (formerly at New Brunswick, New Jersey and now at Argonne, Illinols). Thelr evaluation of the precision, accuracy, and relfability of the system recently has been published ${ }^{28}$; only highlights are presented here. At NBL, a detailed evaluation was made with standards containing from 40 to 140 mg uranium. The computer program was changed slightly so that all samples were determined using the "large sample" electrolysis current sequence ( 300 and $10 \mathrm{~mA}$ ). Also, the slope detection was modifled to select different pre-end point slope values for different sample sizes.

To determine the accuracy and preclsion of the analyzer, NBL made a series of runs over 15 d using three replicates each day at each of six uranium levels (see Table 2). The value at each level therefore represents 45 determinations. There is a significant, Increasingly negative blas occurring in the titration of the larger quantitles of urantum. The cause of this bias has not yet been discovered, but is believed to be due to an Interaction between the catalytic loss of U(IV) and the current efficiency of the titration for the particular size of generator electrode employed. Due to the high precision obtained, NBL recomalends that either the results be corrected using a recovery data calibration or that the sample size be IImited to $50 \mathrm{mg}$.

A varlety of uranium-contalning samples also were analyzed and representative results from Ref. 28 are given in Table 3. The only problem encountered with these samples involved the effect of HF. The Indicator electrode response is more sensitive in the presence of $\mathrm{HF}$. As a result, Insufficlent numbers of data points sometimes were obtained when titrating samples of ore concentrate. Early attempts to titrate

Table 2. Accuracy and preclsion of analyses of urantum standards at the New Brunswick Laboratory. 28

\begin{tabular}{ccc}
\hline $\begin{array}{c}\text { Uranium } \\
\text { titrated, } \\
\text { mg }\end{array}$ & $\begin{array}{c}\text { Mean } \\
\text { recovery, } \\
\%\end{array}$ & $\begin{array}{c}\text { Relative } \\
\text { standard } \\
\text { deviation, } \\
\%\end{array}$ \\
\hline 40 & 100.00 & 0.04 \\
60 & 99.95 & 0.05 \\
80 & 99.90 & 0.03 \\
100 & 99.88 & 0.04 \\
120 & 99.86 & 0.03 \\
140 & 99.81 & 0.04 \\
\hline
\end{tabular}


a solution of U-Zr-Er alloy in $\mathrm{HF}$ also regulted in an error greater than $1 \%$. The effect of fluoride on the titra- tion and a method to prevent etching of the beakers by high concentrations of HF must be addressed in further study.

\section{SYSTEM RELIABILITY}

The prototype system was operational in its nearly final form in the spring of 1975; some of the subsystems were functional in the previous year. The system was tested almost continually until the spring of 1976 , when it was shipped to the New Brunswick Laboratory for a year of thorough evaluation. A brief description of the rellability of varfous subsystems follows.

\section{ELECTROCHEMICAL CELL}

The continual measurement, display, and recording of the titration variables gives the system operator a graphic early warning of spectfic difficulties, thus minimizing downtime. The reference-electrode salt-bridge has never malfunctioned. In addition, the location of the four electrodes and measurement of their potentials with the floating, differentlal-1nput meters have proved very satisfactory. Interrupting the passage of electrolysis current at $300 \mathrm{~mA}$ or decreasing the current (to 100 or $10 \mathrm{~mA}$ ) does not measurably affect the potentiometric measurement. Flame cleaning, followed by $\mathrm{HNO}_{3}$-quenching of the platinum indicator electrode is occasionally required; however, the gold generator electrode has never required cleaning. Similarly, the Nafion-membrane counter-electrode tube has required no maintenance. The stirrer shaft and bushing have been replaced twice.

GAS, WATER, REAGENT, AND WASTE DISTRIBUTION SYSTEM

Except for the flowswitches, the gas, water, solution, and waste distribution subsystems have been quite rellable. The reagent solution dellvery system uses the liquidchromatography-type valves and pressurized containers; this design appears to be quite successful. None of the valves has yet required replacement, reagent delivery volumes have been constant over long perlods of time, and no corrosive chemical spills have been caused by the dellvery system. On the other hand, the flowswitches, which indicate the flows of the various fluids in the system, have not been as relfable as desired. 
Table 3. Comparison of uranium analysas by manual and automated methods. 28

\begin{tabular}{lccc} 
& \multicolumn{2}{c}{ Percent uranium found } & Percent difference, \\
\cline { 2 - 4 } $\begin{array}{c}\text { Sample type } \\
\text { and number }\end{array}$ & $\begin{array}{c}\text { NBL manual } \\
\text { titration }(M)\end{array}$ & $\begin{array}{c}\text { Automated } \\
\text { titration }(A)\end{array}$ & $\frac{A-M}{M} \times 100$ \\
\hline
\end{tabular}

$\underline{\mathrm{UO}_{2}}$

EU $3340 \mathrm{~A}$

EU 3429 A-1

$\mathrm{UO}_{3}$

EU $3829 \mathrm{~A}$

EU $3832 \mathrm{~A}$

$\mathrm{UF}_{6}$

E 1191-1-2

E 1192-1-1

$\mathrm{U}_{3} \mathrm{O}_{8}$

E 2782-1-1

E 2783-1-1

U N1trate

EU 3591-1-1

EU 3592-1-1

U-A1

13.69
87.54

83.91

82.94

82.93

67.58

67.63

85.67

85.67

13.10

85.62

$-0.06$

85.58

$-0.11$

13.07

13.68

$-0.23$

$-0.07$
EU 3659 A

EU $3661 \mathrm{~A}$

Ore Concentrates

F 8200-1

81.00

F 8201-2

80.78

StaInless Steel
E 2440-1-1
0.475
0.398
E 2441-1-2

10.82

10.82

10.81

10.82

81.02

80.85

$+0.02$

$+0.09$

0.00

$-0.09$
0.478

$+0.63$

0.400 
Too of ten, they have stuck in the "on" condition, giving a false indication of a fluid flow. Because the flowswitches have been much less rellable than the operations they were Intended in monltor, we are modifying this approach. The only other components that have deteriorated and required replacement are the polyurethane, pneumatic-valve tubing and the polycarbonate windows of the reagent containment enclosure.

\section{ELECTRONIC SYSTEMS}

With few exceptions, there have been no more than the usual electronic malfunctions and most have resulted in minimum downtime. The most serious problem occurred when the programmable constant-current source, af ter nearly four years of operation, experienced a power supply failure. This was quickly corrected but we did not discover for some time that the failure also had altered the value of the precision resistor that is used to callbrate the constant current. We also experlenced difficulties with several of the commerclally bullt Instruments; however, with replacement modules and factory service, these problems were corrected.

\section{ACKNOWLEDGMENTS}

Valuable work on the fabrication and test of the electronic instrumentation for the titration system was performed by J. R. Elliott. The encouragement, advice, and cooperation of C. D. Bingham and the person- nel of the New Brunswick Laboratory are gratefully acknowledged. Particular thanks are extended to $\mathrm{K}$. Lewis, D. I. Colwell, C. G. Goldbeck, and B. Moran for their careful evaluation of the system. 


\section{REFERENCES}

1. W. Daviers and W. Gray, TaZanta 11, 1203 (1964).

2. A. R. Eberle, M. W. Lerner, G. G. Goldbeck, and C. J. Rodden, Titmimetmic Determination of Uranium in Product, Fuel, and Scrap Matemials After Ferrous Ion Reduction in Phosphoric Acid, New Brunswick Laboratory, Rept. NBL-252 (1970).

3. C. G. Goldbeck and M. W. Lerner, Anal. Chem. 44, 594 (1972).

4. L. Z. Bodnar and J. M. Scarborough, in Annual Progreas Report for the Period July 1972 through June 1973, New Brunswlck Laboratory, Rept. NBL-267 (1973), pp. 22-28.

5. J. V. Bender and J. L. Marley, presented at 28th Pittsburgh Conf. Anal. Chem. Appz. Spectroscopy, Cleveland, Ohio, March 1977.

6. C. G. Goldbeck and M. W. Lerner, in Annual Progress Report for the Period July 1971 through July 1972, New Brunswick Laboratory, Rept. NBL-265 (1972), pp. 5-20.

7. c. G. Goldbeck, M. W. Lerner, and G. E. Peoples, in Annual Progress Report for the Period JuIy 7972 through June 3973, New Brunswick Laboratory, Rept. NBL-267 (1973), pp. 29-31.

8. J. Slanina, F. Bakker, and W. A. Lingerak, In Safeguarding Nuclear Materials (International Atomic Energy Agency, Vienna, 1976), Vol. II, pp. 156-163.

9. G. C. Swanson, presented at 3 2nd Northwest Meeting Amer. Chem. Soc., Portland, Oregon, June 15-16, 1977.

10. J. T. Van Gemert, Talanta 20, 1045 (1973).

11. J. K. Foreman and P. B. Stockwel1, Automatic Chemical Analysis (Halsted Press, New York, 1975), Pp. 95-114.

12. J. S. Fritz and L. Goodk1n, Anal. Chem. 46, 959 (1974).

13. D. G. Mitchel1 and K. M. Aldous, Analyst 98, 580 (1973).

14. J. E. Harrar and C. L. Pomernacki, Chem. Instrum. 7, 229 (1976).

15. HJ. Keller, Neue Teknik 14(2), 31 (1972).

16. M. W. Lerner, New Brunswlck Laboratory, New Brunswick, New Jersey, unpublished work (1974).

17. J. E. Harrar and R. J. Sherry, AnaZ. Chem. 47, 601 (1975).

18. L. H. Koopmans, The Spectral Analysis of Time Series (Academic Press, New York, 1974), pp. 174-176.

19. A. Savitsky and M. J. E. Golay, AnaZ. Chem. 36, 1627 (1964). 
20. J. E. Harrar and W. G. Boyle, Studies of Factors Affecting Uranium Determinations by Automated Coulometric Titration (New Bronowick Laboratory/Davieo-Gray Method), Lawrence LIvermore Laboratory, Rept. UCRL-52060 (1976).

21. L. Z. Bodnar and M. W. Lerner, In Annual Progress Report for the Period July 1973 through Jume 1974, New Brungwick Laboratory, Rept. NBL-262 (1974), pp. 13-25.

22. K. Klinedinst, J. A. S. Bett, J. MacDonald, and P. Stonehart, J. Electroanal. Chem. 57, 281 (1974).

23. J. J. Lingane, Electroanalytical Chemiatry (Intersclence, New York, 1958), 2nd ed., pp. 488-490.

24. J. E. McCracken, J. C. Guyon, W. D. Shults, and H. C. Jones, Chem. 1.zetrum. 3, 311 (1972).

25. W. Krijgsman, H. P. Van Bennkom, and B. Griep1nk, Mikerochim. Acta 1972, 42.

26. I, Anfält and D. Jagner, Aneit. Chim. Acta 57, 165 (1971).

27. J. A. Goldman, J. Electroanci. Chem. 16, 47 (1968).

28. R. Lewis, D. L. Colwe1l, C. G. Goldbeck, and J. E. Harrar, in Proc. 21st Conf. Anat. Chem. Energy Tech., Gatlinburg, Tennessee, October 1977. 